\title{
Archosauriform footprints in the Lower Triassic of Western Alps and their role in understanding the effects of the Permian-Triassic hyperthermal
}

Fabio M. Petti ${ }^{1}$, Heinz Furrer ${ }^{2}$, Enrico Collo ${ }^{3}$, Edoardo Martinetto ${ }^{4}$, Massimo Bernardi ${ }^{1}$, Massimo Delfino ${ }^{4}$ Marco Romano ${ }^{\text {Corresp., } 5}$, Michele Piazza ${ }^{6}$

${ }^{1}$ MUSE - Museo delle Scienze, Trento, Trento, Italy

2 Paläontologisches Institut und Museum, Universität Zürich, Zürich, Switzerland

3 Natura Occitana, Dronero (CN), Dronero (CN), Italy

4 Dipartimento di Scienze della Terra, Università degli Studi di Torino, Torin, Italy

5 Scienze della Terra, University of Roma "La Sapienza", Rome, Italy

6 Dipartimento di Scienze della Terra, dell'Ambiente e della Vita, Università di Genova, Genoa, Italy

Corresponding Author: Marco Romano

Email address: marco.romano@uniroma1.it

The most accepted killing model for the Permian-Triassic mass extinction (PTME) postulates that massive volcanic eruption (i.e. the Siberian Traps Large Igneous Province) led to geologically rapid global warming, acid rain and ocean anoxia. On land, habitable zones were drastically reduced, due to the combined effects of heating, drought and acid rains. This hyperthermal had severe effects also on the paleobiogeography of several groups of organisms. Among those, the tetrapods, whose geographical distribution across the end-Permian mass extinction (EPME) was the subject of controversy of a number of recent papers. We here describe and interpret a new Early Triassic (?Olenekian) archosauriform track assemblage from the Gardetta Plateau (Briançonnais, Western Alps, Italy) which, at the Permian-Triassic boundary, was placed at about $11^{\circ}$ North. The tracks, both arranged in trackways and documented by single, well-preserved imprints, are assigned to Isochirotherium gardettensis ichnosp. nov., and are here interpreted as produced by a non-archosaurian archosauriform (erytrosuchid?) trackmaker. This new discovery provides further evidence for the presence of archosauriformes at low latitudes during the Early Triassic epoch, supporting a model in which the PTME did not completely vacate low-latitude lands from tetrapods that therefore would have been able to cope with the extreme hot temperatures of Pangaea mainland. 
1 Archosauriform footprints in the Lower Triassic of Western Alps and their role in understanding the effects of the Permian-Triassic hyperthermal

$$
\text { Fabio M. Petti }{ }^{1} \text {, Heinz Furrer }{ }^{2} \text {, Enrico Collo }{ }^{3} \text {, }
$$
and Michele Piazza ${ }^{6}$

${ }^{1}$ MUSE - Museo delle Scienze, Trento

2Paläontologisches Institut und Museum, Universität Zürich, Zürich

${ }^{3}$ Natura Occitana, Dronero $(\mathrm{CN})$

${ }^{4}$ Dipartimento di Scienze della Terra, Università degli Studi di Torino, Torino

${ }^{5}$ Dipartimento di Scienze della Terra, Sapienza Università di Roma, Roma

*Corresponding author e-mail: marco.romano@uniroma1.it

ABSTRACT 
24

25

26

27

that massive volcanic eruption (i.e. the Siberian Traps Large Igneous Province) led to geologically rapid global warming, acid rain and ocean anoxia. On land, habitable zones were drastically reduced, due to the combined effects of heating, drought and acid rains. This hyperthermal had severe effects also on the paleobiogeography of several groups of organisms. Among those, the tetrapods, whose geographical distribution across the end-Permian mass extinction (EPME) was the subject of controversy of a number of recent papers. We here describe and interpret a new Early Triassic (?Olenekian) archosauriform track assemblage from the Gardetta Plateau (Briançonnais, Western Alps, Italy) which, at the Permian-Triassic boundary, was placed at about $11^{\circ}$ North. The tracks, both arranged in trackways and documented by single, well-preserved imprints, are assigned to Isochirotherium gardettensis ichnosp. nov., and are here interpreted as produced by a non-archosaurian archosauriform (erytrosuchid?) trackmaker. This new discovery provides further evidence for the presence of archosauriformes at low latitudes during the Early Triassic epoch, supporting a model in which the PTME did not completely vacate low-latitude lands from tetrapods that therefore would have been able to cope with the extreme hot temperatures of Pangaea mainland.

\section{INTRODUCTION}

The Permian-Triassic mass extinction (PTME) was the most severe biotic crisis of all times (Erwin, 1993), eliminating $>90 \%$ of marine and terrestrial species (Erwin, 1993; Song et al., 2013, 2015; Romano et al., 2020). After the mass extinction, totally new clades emerged, which 
46 include decapods and marine reptiles in the oceans and new tetrapods on land (Chen and Benton,

47 2012). In the last decade different physical environmental shocks have been identified as

48 possible triggers for the huge crisis, which include increased atmospheric $\mathrm{CO}_{2}$ concentrations,

49 global warming, acid rain, ocean anoxia, ocean acidification and hypercapnia (Chen and Benton,

50 2012; Benton, 2018). The most accepted killing model (e.g. Benton \& Twitchett, 2003; Chen \&

51 Benton, 2012; Benton \& Newell, 2014; Shen et al., 2019) postulates an initial megascale

52 eruption (more than 1,000 Gigatonnes of erupted lava, see Grasby et al., 2011), that released

53 sulphate aerosols and methane from clathrate reservoirs (see Berner, 2002), which led to global

54 warming and acid rain, causing a generalized plant die-offs and thus intensive erosion of the soil

55 (Wignall, 2001; Benton, 2003, 2018; Benton \& Twitchett, 2003; Sephton et al., 2005; Knoll et

56 al., 2007). On land, habitable zones were drastically reduced, due to the combination of extreme

57 heat, drought and acid rains, which caused progressive loss of soil and forests and had direct

58 impact on lacustrine organisms and any land-dwelling animal (Benton \& Newell, 2014).

59 According to several authors (Joachimski et al., 2012; Sun et al., 2012; Schobben et al., 2014;

60 Song et al., 2015) the intense global warming started at the extinction horizon as testified in the

61 Meishan section (South China). The process continued in the Early Triassic, very likely with the

62 release of methane from deep ocean sediments and coals that triggered the process, and the

63 release of additional greenhouse gases by interactions of the Siberian traps with local permafrost

64 soils, limestones, and other deposits rich in organic matter (e.g. Racki, 2003; Racki \& Wignall,

65 2005; Retallack \& Jahren, 2008; Grasby et al., 2011).

66 The hyperthermal had severe effects also on the paleobiogeographic patterns. In recent years

67 the distribution of land tetrapods across the PTME was discussed in a number of studies which

68 however suggested different scenarios. By compiling literature evidence on the main skeletal 
69 findings, Sun et al. (2012) suggested that, in the Early Triassic, terrestrial vertebrates totally

70

71

72

73

74

75

76

77

78

vacated the equatorial belt, the so-called 'vertebrate equatorial-gap', as a consequence of the extreme hot temperatures. More recently, Bernardi et al. $(2015,2018)$ and Romano et al. (2020)

reviewed the late Permian-Early Triassic terrestrial tetrapod record integrating skeletal and track data and concluded that tetrapod geographic distribution was much wider than previously suggested. In the Early Triassic it included also the low latitudes, though polarward dispersals were detected in the Early Triassic and possibly linked to the development of super-hot temperatures in the equatorial belt (Bernardi et al., 2018). Fossil track evidence, in particular, was key in denying the existence of an 'equatorial gap' (Bernardi et al., 2018; Romano et al., 2020).

Archosaur tracks and trackways are in fact well-known from Lower to Middle Triassic siliciclastic and carbonate sediments of the Upper Buntsandstein and Lower Muschelkalk (late Olenekian-early Anisian) of Germany (Haubold, 1971a, 1971b; Klein \& Haubold, 2007), the Lower Triassic of the Holy Cross Mountains in Poland (Klein \& Niedzwiedski, 2012), the Middle Triassic of Bourgogne (Gand, 1979), Massif Central (Demathieu, 1970) and Ardèche in France (Courel \& Demathieu, 1976), the Iberian Range in Spain (Fortuny et al., 2011; DiazMartinez, et al., 2015) and Sardinia in Italy (Citton et al., 2020). Further sites, often with identical ichnotaxa and ichnoassemblages, are known from the Lower to Middle Triassic of Great Britain (King et al., 2005), North American southwest (Klein \& Lucas, 2010a, 2010b), Argentina (Melchor \& De Valais, 2006), Africa (Klein et al., 2011) and southern China (Xing et al., 2013). In the Alps, chirotherian footprints were described from the upper Permian, Lower to Middle Triassic of the Dolomites, Piedmont and Ligurian Alps in Italy (Avanzini \& Mietto, 2008; Petti et al., 2013; Bernardi et al., 2015; Santi et al., 2015), Aar Massif in eastern 
92 Switzerland (Feldmann et al., 2009; Klein et al., 2016) and the Aiguilles Rouges Massif (Western

93 Alps), on the border between Switzerland and France (Demathieu \& Weidmann, 1982; Avanzini

94 \& Cavin, 2009; Cavin et al., 2012; Klein et al., 2016).

95 We here describe and interpret a new archosaur track assemblage from the Gardetta Plateau

96 (Western Alps, south-western Piedmont, Italy; Fig. 1) that was analyzed in two different field

97 projects, during the summer 2009 and in the autumn 2017-2018.

98 Tracks are preserved on two distinct track surfaces, belonging to the same stratigraphic

99 horizon. Some of them are badly preserved but distinct trackways, up to $3 \mathrm{~m}$ long, can be

100 recognized together with other exceptionally preserved isolated tracks showing clear

101 morphological details of the trackmaker's autopodium.

102 This discovery provides reliable evidence of the presence of archosauriforms in the

103 Briançonnais domain during the Early Triassic, adding further support to the occurrence of

104 terrestrial tetrapods at low latitudes soon after the PTME (Bernardi et al., 2015; 2018; Romano et 105 al., 2020) and well-before a full land ecosystem recovery.

\section{MATERIALS AND METHODS}

All the specimens were identified in the same outcrop, located about $1 \mathrm{~km}$ SE of the Gardetta

111 Plateau, close to Pianezza creek (44²4'5.75"N; $7^{\circ}$ 1'45.29"E; Canosio Municipality, Cuneo

112 Province, NW Italy; Fig. 1). Most of the footprints are preserved as negative epichnia (concave

113 epirelief), and were discovered by EC and MP in summer 2008. A surface of about 10-15 $\mathrm{m}^{2}$ was

114 mapped for the first time in 2009 by HF and then in 2017 by FMP and HF. An exceptionally 
115 preserved trackway, consisting of three large pes and manus imprints, was then discovered

116 during the 2017 and 2018 field seasons by EM and FMP, about $10 \mathrm{~m}$ higher up on the same

117 outcropping horizon.

118 Three tetrapod trackways have been identified from the Gardetta outcrop: GT-1, GT-2 and

119 GT-7. The GT-1 is composed by 4 consecutive footprints whereas GT-2 by 8 footprints. Both

120 trackways were assigned to the ichnogenus Chirotherium and were left in situ in the outcrop. The

121 trackway GT-7 is composed by three consecutive manus-pes sets and was assigned to

122 Isochirotherium gardettensis ichnosp. nov. It was left in situ but the Holotype GT-7-3 was

123 digitally modelled, printed and is now stored at the Museo di Geologia e Paleontologia

124 dell'Università di Torino and digitally stored in MorphoSource (see below). On the same

125 bedding surface where GT-1 and GT-2 trackways are preserved, few other isolated footprints

126 were found (GT-3, GT-4, GT-5, GT-6). All of them were left in situ. GT-3 was assigned to

127 Isochirotherium isp. GT-4, GT-5, GT-6 were not assigned to any existing ichnotaxon because

128 poorly preserved. GD-E1, GD-E2 and GDE-12 are specimens that were found as solitary

129 footprints from loose slabs (erratic) and are currently stored at the Museo di Geologia e

130 Paleontologia dell'Università di Torino. The specimen number, taxonomic affinities and

131 repository for all the considered ichnological material from Gardetta is summarized in Table 1.

132 Tracks outlines were drawn on transparency acetate film and then digitized by a vector-based

133 drawing software (Adobe Illustrator (C)). Additional footprints were collected by the authors and

134 hikers from loose sandstone slabs in the creek below the track surfaces. These isolated and

135 usually fragmentary footprints are preserved both as concave epirelief and well-preserved

136 convex epirelief, the latter being preserved in the basalmost level of the sandstone bed which

137 overlies the track layer. 
Close-range photogrammetry was used to document tracks and obtain three-dimensional 139 model of the best-preserved ones (Petti et al., 2008; Remondino et al., 2010; Mallison \& Wings, 2014). The data processing phase was performed using Agisoft PhotoScan ${ }^{\circledR}$ Professional

141 software, following the procedure indicated by Mallison \& Wings (2014). In a second phase, the 142 software Surfer ${ }^{\circledR} 14$ (GoldenSoftware, 2002), was used to convert elevation points to contour

143 lines and to produce color coded maps of the studied material. The obtained images are ideal for 144 both precisely-measured standard ichological parameters (Haubold, 1971b; Leonardi, 1987) and 145 for recognizing anatomy related morphologies, therefore for the reconstruction of the 146 trackmaker's autopodial osteology.

147 The search for a putative trackmaker was carried out employing three different and integrated 148 methodological approaches: i) Synapomorphy-based correlation (Olsen, 1995; Carrano \& 149 Wilson, 2001); ii) Phenetic correlation (Carrano \& Wilson, 2001) and iii) Coincidence 150 correlation (Carrano \& Wilson, 2001). The synapomorphy-based method focuses on the 151 identification of osteologic-derived character states in the footprints that result from the 152 impression of synapomorphic characters in the trackmaker autopodia (see Olsen et al., 1998;

153 Carrano \& Wilson, 2001; Wilson, 2005; Romano et al., 2015). The phenetic correlation is 154 closely linked to ichnotaxonomy and derives from an accurate description of the footprint and 155 the identification of the trackmaker through the recognition of an affinity between tracks and 156 autopods osteology (Carrano \& Wilson, 2001; Wilson, 2005). The coincidence correlation is 157 usually adopted to refine trackmaker identification and is based on supplemental data including 158 geological age, geographic provenance, local faunal composition and distributions, and 159 abundances of skeletal taxa and ichnotaxa (Carrano \& Wilson, 2001). 


\section{Nomenclatural acts}

The electronic version of this article in Portable Document Format (PDF) will represent a published work according to the International Commission on Zoological Nomenclature (ICZN), and hence the new names contained in the electronic version are effectively published under that Code from the electronic edition alone. This published work and the nomenclatural acts it contains have been registered in ZooBank, the online registration system for the ICZN. The ZooBank LSIDs (Life Science Identifiers) can be resolved and the associated information viewed through any standard web browser by appending the LSID to the prefix http://zoobank.org/. The LSID for this publication is: urn:1sid:zoobank.org:pub:654063D7-8AE9-4F4A-A6E9-

E518F3D6B79E. The online version of this work is archived and available from the following digital repositories: PeerJ, PubMed Central and CLOCKSS.

\section{GEOLOGICAL FRAMEWORK}

The Gardetta Plateau - Preit valley area is located in the southern part of the Western Alps (Fig. 1). It encompasses the Sautron, Rouchouze, Rocca Peroni tectonic units and the Gardetta deformation unit (sensu d'Atri et al., 2016) also known as "bande siliceuse de la Gardetta" (Gidon, 1972).These tectonic units pertain to the Briançonnais Domain (Gidon, 1958a, 1958b, 1972; Schmid et al., 2004, 2017) and in particular to the External Briançonnais Domain which is characterized by very low grade to anchizone metamorphism (d'Atri et al., 2016).

$$
\text { The upper Permian-Mesozoic sedimentary succession varies considerably within the }
$$

Briançonnais Domain s.l. (Briançonnais Domain s.s. and Ligurian Briançonnais, Decarlis \& Lualdi, 2009; Fig. 2) due to the slightly different paleogeographic positions of these sectors (see 
184 Decarlis et al., 2013 for a review). The outcropping lithostratigraphic units, even if they can be

185

186

187

188

189

190

191

192

193

194

195

196

197

198

199

200

201

202

203

204

205

206

correlated across the distinct domains, display different thickness, vertical/lateral relationships

and hiatuses. These differences led authors to adopt a multitude of official and unofficial names

for the lithostratigraphic units. Despite these minor differences, the late Permian-Early Triassic sedimentation in the whole Briançonnais domain s.l. testifies to the evolution of a continental margin affected by extensional tectonics. The Briançonnais domain was positioned north of the westernmost sector of the Palaeotethys, in the western continental termination of the Meliata oceanic back-arc basin (Ziegler \& Stampfli, 2001; Decarlis et al., 2013). Adopting the paleolatitude calculator developed by Van Hinsbergen et al. (2015) (model version 2.1) and using the Global Apparent Polar Wander Path of Torsvik et al. (2012) as the paleomagnetic reference frame, the Early Triassic (250 Ma) palaeolatitude estimate for the Southern Briançonnais Domain is $11.8 \mathrm{~N}$.

In the study area the volcano-sedimentary succession starts with upper Carboniferous Permian volcanic rocks (andesitic lavas followed by rhyolites and rhyolitic ignimbrites) unconformably overlain by upper Permian-Lower Triassic siliciclastic continental-to-transitional deposits (the so called "semelle silicieuse" of French authors). In particular these deposits are characterized by basal coarse grained conglomerates and quartz-conglomerates, named locally "Verrucano Brianzonese" (Carraro et al., 1970; Cassinis et al., 2018), that evolve upward into quartz-arenites and quartz-siltites of the "Werfenian quartzites" (Fig. 2; Gidon, 1958b; Malaroda, 1970; Megard-Galli \& Baud, 1977; Costamagna et al., 2002; Costamagna, 2013). The siliciclastic sequence indicates deposition in an alluvial environment characterized by sandy braided fluvial system fed by the residual Variscan relief (Costamagna, 2013). In the southernmost part of the Briançonnais domain (External Ligurian Briançonnais Domain, 
207 Vanossi, 1974, 1991; Bertok et al., 2012) these latter lithostratigraphic units are known as

208 "Scytian quartzites" or "Ponte di Nava Quarzites" (Fig. 2; Decarlis et al., 2013, 2015). Similar to

209 the siliciclastic sequence of the Briançonnais Domain s.s., the "Ponte di Nava Quarzites"

210 originated from the dismantling and reworking of the Paleozoic igneous and metamorphic

211 basement.

212 The quartz-arenites can be topped either by greenish pelites (known as "Case Valmarenca

213 Pelites" in the Ligurian Briançonnais, Vanossi 1974, 1991), that have been interpreted as mudflat

214 deposits, or by a thin and discontinuous interval of cavernous dolostones called "Cargneules

215 Inférieures" representing the sedimentation in an arid environment as an evaporitic sabkha (Fig.

216 2). According to Lualdi \& Seno (1984), in the Ligurian Briançonnais Zone the "Case

217 Valmarenca Pelites" could be laterally equivalent to the "Cargneules inférieures".

218 The continental succession and/or the evaporitic deposits are followed by Middle Triassic

219 shallow water carbonates of the "couverture carbonatée" (Gidon, 1958b; Megard-Galli \& Baud,

220 1977; Costamagna et al., 2002) comprising a lower calcareous complex (Costa Losera

221 Formation, Lualdi and Bianchi, 1990, corresponding to the e St. Triphon Formation of the classic

222 Briançonnais Domain) and an upper dolomitic complex (San Pietro dei Monti Formation,

223 Vanossi, 1969). These carbonate deposits testify the sedimentation in a subsiding carbonate

224 ramp.

225 The lower calcareous complex (Fig. 2) begins with a characteristic facies named "Marbres

226 Phylliteux" by French authors made of greyish and brownish fine-grained limestones, (lower to

227 upper Anisian) with sericite, muscovite, chlorite laminated levels. Bedding can be locally

228 masked by pervasive and intense bioturbation ("Calcaires Vermiculés" facies) assigned to the

229 ichnogenus Rhizocorallium. The basal complex ends with varicolored pelites, interpreted as 
230 cinerites (upper Anisian in age) by Caby \& Galli (1964), recognizable throughout the whole

231 Briançonnais Domain.

232 The upper dolomitic complex (Fig. 2) is comprised of massive to well-bedded dolostones

233 followed by cyclically arranged carbonates ("Calcaires rubanés" - upper Anisian - upper

234 Ladinian; Gidon, 1958b; Megard-Galli \& Baud, 1977; Costamagna et al., 2002; Decarlis \&

235 Lualdi, 2009) characterized by subtidal crinoidal wackestones, intertidal oolitic limestones and

236 supratidal dolomitic mudstones capped by reddish paleosols, that testify shallowing-upward

237 cycles. The dolomitic succession includes dark limestones, dark fossiliferous and/or oolithic

238 dolostones, meter-thick autoclastic breccias and gypsum-anhydrite pseudomorphs witnesses of

239 major emersion events. These lithofacies, dated to the uppermost Ladinian, are known in the

240 different Briançonnais domains as "Dolomies blanches" or "Dolomies grises" or "Couches a $C$.

241 goldfussi" or "Complexe schisto-dolomitique basal".

In the framework of the above mentioned stratigraphic setting the footprint-bearing level is located in the Pianezza area along the track connecting Colle del Preit (2100 m a.s.l.) to Grange Isoardi (Pianezza area, $2275 \mathrm{~m}$ a.s.1.) (Fig. 2). The outcrop is located along the SW flank of a narrow antiformal anticline belonging to the Sautron Tectonic Unit which overthrusts the Rouchouze Tectonic Unit. Here the volcano-stratigraphic succession begins by meta-andesites and andesitic schists pertaining to the upper Carboniferous-Permian volcanic complex. The sedimentary succession continues upward with a thin and discontinuous (up to 1 meter) level of 
253 graphitic schists, deriving from the weathering of the volcanic basement (Lorenzoni \& Zanettin,

254 1958) and is then followed by up to 100 meters of quartz-conglomerates ("Verrucano

255 Brianzonese") and by fine to very fine quartz-arenite and quartz-siltite with ripple marks and

256 cross bedding (“Werfenian quartzites"). The track-bearing horizon occurs at the top of the latter

257 clastic interval. The succession continues upward with 15 meters of gypsum/anhydrite deposits

258 of the lower cargneule. In the Pianezza area the Middle Triassic "couverture carbonatée" is only

259 represented in the north-eastern flank of Sautron Unit anticline.

\section{CHRONOSTRATIGRAPHIC FRAMEWORK OF THE STUDY AREA}

264 The sedimentary rock belonging to the quartz-rich clastic succession does not allow precise 265 dating because of the lack of biostratigraphic markers as commonly happen for these kind of 266 deposits. They are here referred to the upper Permian-Lower Triassic at the base of their

267 stratigraphic position in the Sautron Unit, similar to that of the very comparable quartz-

268 conglomerate and quartzarenite rocks occurring not only in the Briançonnais Domain, but also in

269 the Southern Alps, Sardinia and Provence. For this reason, in order to constrain the age of the

270 track-bearing horizon, some considerations are required: i) the coarse quartz-conglomerates

271 ("Verrucano Brianzonese") are commonly referred to the late Permian-earliest Triassic (Gidon,

272 1958b; Carraro et al., 1970; Megard-Galli \& Baud, 1977; Decarlis \& Lualdi, 2009); ii) the Lower

273 Triassic age can be hypothesized considering the occurrence of Estheria minuta and Myacites

274 fassaensis within the "Ponte di Nava Quarzites" (Decarlis \& Lualdi, 2009); iii) the "lower

275 cargneule" unit and its lateral equivalent "Case Val Marenca Pelites" are generally attributed to 
276 the late Early Triassic (Gidon, 1958b; Carraro et al., 1970; Megard-Galli \& Baud, 1977; Decarlis

277 \& Lualdi, 2009); iv) the lower parts of "Marbres Phylliteux" are considered early Anisian in age,

278 on the basis of the occurrence of Rhizocorallium, that is regarded as an early Anisian marker all

279 over the Tethyan realm (Baud, 1976); v) an early Anisian age for the base of the lower

280 calcareous complex ("Marbres Phylliteux" and Costa Losera Formation) is also suggested by the

281 occurrence of Dasycladacean algae and crinoidal remains (Dadocrinus sp.; Carraro et al., 1970);

282 vi) In the northern Briançonnais of southwestern Switzerland a find of the ammonoid Beyrichites

283 cadoricus in the upper part of the St-Triphon Formation indicate a middle Anisian age (Baud et

284 al., 2016).

285 Additionally, it is worth mentioning that both in the Geological Map of the Argentera Massif

286 (Malaroda, 1970; Carraro et al., 1970) and in the Geological Map of France at the scale 1: 50.000

287 (Sheet 896, Larche; Gidon, 1978) the studied outcrop was attributed to Lower Triassic. All the

288 above reported data thus point to a probable attribution of the trampled horizon to the late Early

289 Triassic.

290

291

292

SYSTEMATIC ICHNOLOGY

293

294

Most footprints are preserved as natural molds (concave epirelief) on top of a 3-4 cm thick

bed of fine sandstone. The tracks are shallow, less than $2 \mathrm{~cm}$ deep, but most of them are cut by

small-scale tectonic cracks/fissures and strongly weathered. Two possible trackways with lengths of 4-5 m were identified on a track surface. Only one isolated track was visible on the 
299 level. Three solitary small footprints (GD-E1, GD-E2, GD-12), preserved as convex epirelief of

300 the directly overlying sandstone bed, were collected from loose slabs and are currently stored at

301 the Museo di Geologia e Paleontologia dell'Università di Torino (Turin, Italy). The upper

302 surface of this $1-2 \mathrm{~cm}$ thick sandstone bed is marked by symmetric wave ripples, exposed on a 303 spectacular bedding plane (Fig. 3).

304 An exceptionally preserved trackway, comprised of three consecutive manus-pes sets was 305 found on another surface, belonging to the same stratigraphic horizon, upstream of the 306 previously described ones (Fig. 4). The general features of the herein studied ichnoassemblage 307 are typical for chirotherian tracks (Haubold \& Klein, 2002).

\section{Chirotherium isp.} consists of four clear and two weakly impressed imprints, arranged in a $2.10 \mathrm{~m}$-long trackway in the lower part of the outcrop, just 2 meters above the creek level (Fig. 3). Its direction on the steep bedding plane points upwards to southeast. Trackway GT-2 is $2.40-\mathrm{m}-\mathrm{long}$, is preserved in 
321 Description: pentadactyl and semi-digitigrade pes imprint. Pes is longer than wide, (Foot

322 Length $[\mathrm{FL}]=13$ to $16 \mathrm{~cm}$; Foot Width $[\mathrm{FW}]=8-10 \mathrm{~cm} ; \mathrm{FL} / \mathrm{FW}=1.6$ to 2.0 ) with digit group

323 II-IV roughly asymmetrical. Pedal digit impressions gradually increase from I to IV, with II sub-

324 equal or shorter than digit IV; digit III is the longest. In the best-preserved track (GT1-3; Figs 3,

325 5), digit I impression is pointed and placed posteriorly with respect to digit group II-IV. Digit V

326 impression is oval and tapers distally; it is positioned posteriorly and laterally to digit I-IV

327 imprints and directed antero-laterally. No digital pad impressions can be observed on digit II-IV.

328 Digit V impression shows a large rounded pad impression and a possible sub-triangular shaped

329 claw mark. Manus tracks are absent or faintly preserved as small semi-circular imprints, placed

330 in front of the pedal footprints. An isolated tetradactyl imprints, measuring $4.5 \mathrm{~cm}$ in length and

$3317 \mathrm{~cm}$ in width, and another isolated circular pentadactyl imprint $5.5 \mathrm{~cm}$ long are interpreted as

332 possible manus imprints.

333 In the trackway the oblique pace varies between 26 and $41 \mathrm{~cm}$, with a mean value of $36 \mathrm{~cm}$.

334 The pes pace angulation varies between $145^{\circ}$ and $165^{\circ}$, with a mean value of $157^{\circ}$.

Discussion: the ichnogenus Chirotherium with its holotype Chirotherium barthii, was described by Kaup (1835) on trackways from the "Thüringischer Chirotheriensandstein" (Lower-Middle Triassic) of the Thuringia region (Germany). The here described material, even if not perfectly preserved, retains some diagnostic features of the ichnogenus Chirotherium, such as the oval morphology and the position of digit $\mathrm{V}$ imprint (slightly behind digit group II-IV), and the relative digit length of group II-IV, with digit IV longer or sub-equal to digit II impression.

342 Pes pace angulation is also similar to the values to date reported for the ichnogenus $\left(160^{\circ}-170^{\circ}\right)$.

343 Chirotherium barthii (Figs 5e, 5f) shows clear circular pads on digit group II-IV and digit 
344 impressions are broader than in the studied specimens. In C. barthii, as well as in C. rex, $C$.

345 moquinense and C. vorbachi (Fig. 5h), digits I-IV imprints are splayed whereas in the GT-1 and

346 GT-2 trackways, pedal digits outlines are closely arranged with only digit I impression medially

347 spread. Digits II-IV imprints seems to be almost parallel to each other and the digit pattern

348 resemble that of the ichnospecies $C$. sickleri Kaup, 1835 (Figs 5i, 51, 5m) with digit I forming a

349 narrow group with digits II, III and IV. Nevertheless, digit IV impression, though slightly shorter

350 than III, is not much longer than II as observed in most of the specimens assigned to C. sickleri.

351 Unfortunately, the bad preservation of pes imprints in GT-1 and GT-2 trackways precludes any

352 accurate ichnospecific assignment.

353

354

355

Ichnogenus Isochirotherium Haubold, 1971a (Figs 4, 6-8)

Type ichnospescies: Isochirotherium soergeli (Haubold, 1967).

356

357

Isochirotherium gardettensis ichnosp. nov.

358

359

Derivatio nominis: from the Gardetta plateau, type locality of the ichnospecies.

360

361

Type-level: "Werfenian quartzites”, Lower Triassic.

362

363

Holotype: cast MGPT-PU135785 (Museo di Geologia e Paleontologia dell’Università di 364

Torino, Italy) printed after the 3D-modelling of the GT-7-3 manus-pes couple. The 3D model of

the holotype is digitally stored in MorphoSource at the permanent link

366

https://www.morphosource.org/Detail/SpecimenDetail/Show/specimen_id/45431 
368 Referred specimens: a trackway made of three exceptionally-preserved (value 3 of the

369

370

371

372

373

374

375

376

377

378

379

380

381

382

383

384

385

386

387

388

389 numerical scale proposed by Belvedere \& Farlow, 2016) and consecutive manus-pes couples

(GT-7; Fig. 4) not exceeding $2.20 \mathrm{~m}$ across. Another possible isolated track (GT-3) partially

preserved in the lower track surface.

Diagnosis: chirotherian track with pentadactyl pes impression and small and tetradactyl

manus imprint; pes digit IV impression noticeably shorter than II; pes digit group I-IV imprint slightly longer than wide, pes digit $\mathrm{V}$ impression with large ovoid pad and a reduced phalangeal portion. Manus is digitigrade with no impression of digit proximal sole-pad (i.e. ulnare-radiale fleshy pad) and digit $\mathrm{V}$.

Digit II and III impressions fairly parallel both in manus and pes. Manus consistently smaller than the pes and placed medially in front of the pes; manus digit III impression parallel to digit III trace of the pes. Cross axis equal to $90^{\circ}$. Trackway very narrow, pace angulation near $165^{\circ}$, and ratio of stride to pes length is 4.3 .

Description: pentadactyl and semi-plantigrade pes imprint, longer than wide $(\mathrm{FL}=33.4 \mathrm{~cm}$; $\mathrm{FW}=19.2 \mathrm{~cm} ; \mathrm{FL} / \mathrm{FW}=1.74)$. Digit III impression is the longest. It is slightly longer than II, whereas digit IV imprint is shorter than II. Digit I impression is the shortest and is thinner than those of digit group II-IV. The total divarication I-IV is $22^{\circ}$; the angle between digit I and II is $8^{\circ}$ and is equal to that between the impressions of II and III but larger than II-IV $\left(6^{\circ}\right)$. Cross axis is nearly equal to $90^{\circ}$. Digit impressions are robust and pointed showing large sub-triangular claw marks. Three to four phalangeal pad impressions are present on each digit of group I-IV. The 
390

391

392

393

394

395

396

397

398

399

400

401

402

403

404

405

406

407

408

409

410

411

412

impression of metatarsal-phalangeal portion is proximally arched and could be separated from digit $\mathrm{V}$ by a gap, or joined with it through a convex area, running from the basalmost portion of digit I to the medial digit V. Digit V impression shows a large oval impression joined to a rounded phalangeal-ungual portion, laterally spread out. In GT-7-2 and GT-7-3, pes digit V impression has a sub-triangular shape with a wider inner margin, almost aligned with the medial margin of digit I. Length of pes digits impressions are: I) $118 \mathrm{~mm}$; II) $173 \mathrm{~mm}$; III) $186 \mathrm{~mm}$; IV) $136 \mathrm{~mm}$; V) $167 \mathrm{~mm}$.

The manus print is small, tetradactyl and digitigrade, wider than long $(\mathrm{FL}=8.04 \mathrm{~cm} ; \mathrm{FW}=13$ $\mathrm{cm} ; \mathrm{FL} / \mathrm{FW}=0.62)$ and is placed in front of the pes print. Digit impressions are short and pointed. Digits II and III have nearly equal length and are longer than digits I and IV; the latter is moderately spread outward. One pad impression is visible on digits I and IV whereas three pads characterize digits II and III. Digit IV impression is possibly the shortest. Length of manus digits are: I) $49 \mathrm{~mm}$; II) $74 \mathrm{~mm}$; III) $68 \mathrm{~mm}$; and IV) $43 \mathrm{~mm}$.

The trackway, made by three consecutive manus-pes sets, shows a clear narrow gait (pace angulation $164^{\circ}$ ). Oblique pace is $59 \mathrm{~cm}$, whereas double pace is $119 \mathrm{~cm}$ across. Manus-pes couples turned slightly outward with respect to the midline (from $10^{\circ}$ to $15^{\circ}$ on average).

Discussion: the ichnogenus Isochirotherium was erected by Haubold (1971a); its type ichnospecies I. soergeli (Haubold, 1967) comes, as for Chirotherium barthii, from the "Thüringischer Chirotheriensandstein" (Lower-Middle Triassic) of the Thuringia region (Germany). The ichnogenus is reported also from the Middle Triassic of Great Britain (Tresise \& Sarjeant, 1997; King et al., 2005), from the Lower-Middle Triassic of North American Southwest (Peabody, 1948; Klein \& Lucas, 2010a, 2010b), the Aiguilles Rouges Massif 
413 (Western Alps) on the border between Switzerland and France (Avanzini \& Cavin, 2009; Klein et 414 al., 2016) and from the Middle Triassic of North-East Italy (Avanzini \& Leonardi, 2002).

415 The main diagnostic features of this ichnogenus, recognized in our specimens are: i) the

416 relative digit length, with digit II longer than IV and shorter than III; ii) a marked heteropody; iii)

417 the pes pace angulation around $165^{\circ}$; iv) the weakly impressed distal portion of digit $\mathrm{V}$ and $\mathrm{v}$ )

418 pes-manus couples outward rotation of about $15^{\circ}$. However, the studied trackway shows clear

419 difference to most of the ichnospecies known to date. For example, the type ichnospecies $I$.

420 soergeli Haubold, 1967 (Fig. 8o), has smaller absolute dimensions (even if size is not necessarily

421 diagnostic), thinner pes digit marks and, most importantly, display five clear digit impressions in

422 the manus contrary to GT-7, where only tetradactyl manus were observed.

423 Isochirotherium hessbergense Haubold, 1971a (Fig. 8m) has also a pentadactyl manus placed

424 more closely to pes digit tips and is clearly different from the material described herein for its

425 digit group I-IV longer than wider, for the relative pes digit length, (notably digit I is longer than

426 IV) and proportionally stouter digit impressions.

427 Isochirotherium demathieui Haubold, 1971a (Fig. 8n) can be excluded for its pentadactyl

428 manus and for the shorter distance between manus and pes. Additionally, digits III and IV pes

429 impressions are stouter than in I. gardettensis and the medial embayment is more pronounced;

430 sole-pad pes impression in I. demathieui is consistently smaller.

431 Isochirotherium coltoni Peabody, 1948 (Fig. 8h) and I. lomasi Baird, 1954 (Fig. 8i) retain

432 much slenderer digit impressions, especially in the pes imprint and most notably have manus

433 tracks more internally placed and placed closely to pes digit tips than in the studied material. The

434 proximal sole-pad pes impression is consistently smaller than I. gardettensis, especially in $I$.

435 coltoni. I. lomasi differs from all other ichnospecies in having all digit phalangeal pes impression 
436 quite well-separated for their entire length. In addition, in I. lomasi pes digit group I-IV is

437 detached from digit $\mathrm{V}$.

438 I. herculis Egerton, 1839 (Fig. 8e) can also be excluded for i) the tridactyl manus; ii) the digit 439 group I-IV slightly wider than longer and iii) the manus imprint position, very close to that of the 440 pes and placed in front of pes digit tips II-III whereas in I. gardettensis is projected medially in

441 front of digit II tip In I. herculis pes digit traces are stouter than in the studied specimens and the 442 sole-pad is consistently broader with a fairly absent medial embayment.

443 Isochirotherium marshalli Peabody, 1948 (Fig. 8f) shows similar features such as: i) the pes

444 digit relative length; ii) the interdigital angles values; iii) the digit group I-IV as longer as wider;

445 iv) the arched metatarsal-phalangeal portion; v) the configuration of digit V whose phalangeal

446 portion is significantly smaller than the ovoidal and possibly tarsal-metatarsal pad. Furthermore,

447 in I. marshalli the proximal pes sole-pad impression is more centrally located behind digit II and

448 III whereas in I. gardettensis lies more externally behind digit group III-V.

449 Isochirotherium infernense Avanzini \& Leonardi, 2002 from the Illyrian (late Anisian, Middle

450 Triassic; Fig. 8g) of the Adige Valley (Bolzano, NE Italy) closely resembles the Gardetta

451 specimens for: i) the arched metatarsal-phalangeal portion; ii) the position of the base of pes digit

$452 \mathrm{~V}$, placed along the axis of digit III; iii) pes digit relative length; iv) cross axis equal to $90^{\circ} \mathrm{v}$ ) pes 453 angulation of about $160^{\circ}$; vi) positive rotation of manus-pes couples respect to the midline $\left(10^{\circ}\right.$ -

$4541^{\circ}$ ). However, pes digits are stouter and the manus is described as pentadactyl (even if in the 455 outline drawing only four digits are clearly appreciable) and more importantly interdigital angles 456 are consistently wider, especially between digits II and III that are roughly parallel in $I$.

457 gardettensis. Manus tracks in I. infernense is located frontally to digit II and III rather than 
458 medially as in I. gardettensis. Sole-pad pes impression is consistently smaller than in $I$.

459 gardettensis.

460 The tracks referred to Isochirotherium delicatum Courel \& Demathieu, 1976 and found in the

461 Anisian-Ladinian deposits of Argentière (Ardèche, France; Courel \& Demathieu, 1976; Courel et

462 al., 1979; Demathieu, 1984; Gand, 1978) and Gampempass (Southern Alps, Italy; Avanzini \&

463 Lockley, 2002) show less-thick digit impressions and a markedly reduced digits IV and V; the

464 latter is also much more backward positioned if compared with the studied specimens. Overall

465 pes impression in I. delicatum is consistently longer than wider with a laterally-compressed

466 general appearance.

467 We therefore erect the new ichnospecies Isochirotherium gardettensis to describe a new and

468 exceptionally-preserved Isochirotherium trackway that differs from all the other ichnospecies for 469 all the features listed above.

SEARCHING FOR A PUTATIVE TRACKMAKER

Grounding on previous studies and new observations, Bernardi et al. (2015) showed that chirotherian footprints, such as Protochirotherium, Chirotherium, Brachychirotherium and Isochirotherium, can be confidently attributed to archosauriforms, based on the presence of a digit IV shorter or as long as digit III. Being metatarsal length directly proportionate to digit

477 length, this assumes that metatarsal IV is shorter than or as long as metatarsal III, a 478 synapomorphy of the archosauriforms (Nesbitt, 2011). Other characters useful to identify 479 archosauriforms traces are: i) the presence of a compact digit group I-IV; ii) a posterolateral 480 positioned and strongly reduced digit V; iii) a massive metatarsal-phalangeal region, shorter than 
481 or as long as digit I. However, the first character occurs in archosauriforms and non

482 archosauromorphs diapsids (Haubold, 1971a, 1971b; Smith \& Evans, 1996) whereas the second

483 is present in archosauromorphs (including non-archosauriforms) and lepidosaurs (Haubold,

484 1971a, 1971b; Evans \& Wang, 2005; Gottman-Quesada \& Sander, 2009).Other features

485 suggesting an archosaur-grade affinity for chirotherian footprints (observed also in the here

486 described traces), are narrow trackways linked to the disposition of limbs under the body, and the

487 presence of small manus relative to the pes, which indicate a possible early tendency toward

488 bipedal posture and gate (see Haubold, 1971a, 1971b, 1984, 2006; Klein et al., 2010).

489 To reconstruct the hind- and fore-limb autopodial bones, we assumed an arthral position for

490 the joint articulations within digital pad impressions although aware that this condition is not

491 proven and that the disposition of pads could lie at the phalangeal joints (Fig. 7).

492 In our opinion, the sub-elliptical to pyriform impression behind group I-IV in Isochirotherium

493 could be the result of the coalescence of the impression of the phalangeal-metatarsal portion of

494 digit $\mathrm{V}$ and of a thick fleshy pad beneath the astragalus, the calcaneus and some of the tarsal

495 bones. Overall, the trackmaker's pes may have had a semi-plantigrade posture, as evidenced by

496 the gap between digit group I-IV and digit V, corresponding to the part of the foot held up during

497 locomotion. The manus has a marked digitigrade posture and its tetradactyly might result by the

498 fact that manual digit V likely held off the ground during the touch-down and weight bearing

499 phases (sensu Manning, 2004).

500 The reconstructions thus obtained shows the following pes and manus phalangeal formulas:

501 pes 2-3-4-4-1 and manus 1-2-3-3. They are compared with the anterior and posterior limbs of the

502 main groups of archosauriforms known in the Triassic period (Huene, 1902; Broom, 1903; 1905; 
503 Romer, 1971; Welles, 1947; Young, 1964; Zhang, 1975; Peyer et al., 2008; Ezcurra et al., 2013;

504 Sookias \& Butler, 2013; Trotteyn et al., 2013).

505 The first considered non-archosaurian archosauriforms groups are Proterosuchidae (Ezcurra et 506 al., 2013), Proterochampsidae (Trotteyn et al., 2013) and Euparkeriidae (Sookias \& Butler, 507 2013). In all the three representatives Proterosuchus fergusi Broom, 1903 (South Africa, 508 Induan-?early Olenekian; Fig. 9e), Chanaresuchus bonapartei Romer, 1971 (Argentina, 509 Ladinian; Fig. 9i) and Euparkeria capensis Broom, 1913 (South Africa, Anisian; Fig. 9h), the IV 510 metarsal has a length similar or greater than that of the III but the digit II is much shorter than

511 digit III and nearly equal to digit IV, in contrast to what we observe in specimens GT-7-1, GT-7-

5122 and GT-3. Only disarticulated limb bones are known for the Doswelliidae (Schoch \& Sues, 513 2014), another clade of non-archosaurian archosauriforms (Middle-Late Triassic; Sues et al., 514 2013).

515 Diedrich (2015) recently attributed the Isochirotherium tracks to Arizonasaurus Welles, 1947, 516 a member of Poposauroidea (Archosauria, Pseudosuchia) found in the Moenkopi Formation 517 (Arizona, USA, Anisian,), from the same levels as Isochirotherium tracks. Unfortunately, no 518 bones of the fore- and hind-limbs are known from Arizonasaurus, as well as from 519 Ctenosauriscus koeneni (Huene, 1902) (Germany, latest Olenekian), a Lower Triassic 520 poposauroid archosaur, and additionally findings are needed to test Diedrich's hypothesis. 521 The hind-limb bones are known in Lotosaurus adentus Zhang, 1975 (China, Ladinian; Fig. 522 9d), another member of Poposauroidea with semi-plantigrade posture. If compared with the 523 restored autopodium, it is characterized by larger fore-limbs, digit V positioned further forward, 524 longer metatarsals of digit group I-IV and different digit proportions. 
525 The pedal phalangeal relative length of the "rauisuchid" archosaur Postosuchus alisonae

526 Peyer et al., 2008 (USA, Norian; Fig. 9c) is similar but all the five metatarsals are much longer,

527 implying a digitigrade posture, as in the reconstruction proposed by Peyer et al. (2008).

528 Postosuchus kirkpatricki Chatterjee, 1985 (USA, Norian; Fig. 9b), is also characterized by

529 very long metatarsals and thus excluded as a possible trackmaker. The smaller but complete

530 skeleton of Ticinosuchus ferox Krebs, 1965 (see Lautenschlager \& Desojo, 2011 for a review of

531 the species) from the uppermost Anisian of Monte San Giorgio (southern Switzerland), shows

532 long metatarsals and a digit IV longer than digit II and is commonly considered as the producer

533 of Chirotherium trackways (Haubold, 1984, 1986).

534 By contrast, the hind limbs of the non-archosaurian archosauriform clade of Erythrosuchidae

535 (Ezcurra et al., 2013) are characterized by relative digit length very similar to that outlined for

536 Isochirotherium gardettensis and a pedal phalangeal formula that is approximately 2-3-4-5-3

537 (Young, 1964; Cruickshank, 1978; Gower, 1996).

538 Metatarsals II and III are sub-equal and slightly longer than IV in Erythrosuchus africanus

539 Broom, 1905 (South Africa, lower Anisian; Fig. 9f. See also Cruickshank, 1978; Gower, 1996).

540 Metatarsals II and III are the longest in Shansisuchus shansisuchus Young, 1964 (Fig. 9g),

541 another member of Erythrosuchidae found in upper Anisian deposits of China; S. shansisuchus

542 also possesses a hook-shaped proximal end of metatarsal $\mathrm{V}$ and its relative digit proportion

543 closely fits that of our individual, but as for E. africanus digit V seems to be too forwardly

544 positioned. However, digit V impression in I. gardettensis likely records only the distal

545 metatarsal and phalangeal (ungual) portions. During locomotion the former was held off the

546 ground whereas the latter was likely being retracted due to the presence of a thick fleshy pad

547 beneath calcaneum and astragalus. 
548 The morphology of the acetabulum and proximal end of the femur in erythrosuchids suggests

549 a distinctly sprawling gait (Gower, 2003; Ezcurra et al., 2013), that clashes with the narrow

550 trackway seen in I. gardettensis. Nevertheless, the prominence of metatarsal II and III is

551 evidenced only in non-archosaurian archosauriforms (Gower, 1996) and thus an individual

552 belonging to this group, possibly a yet unknown taxon and with a more erect stance and

553 characterized by a marked heteropody, is the most suitable producer (Fig. 10).

554

555

BIOCHRONOLOGY AND BIOGEOGRAPHY

556 The Gardetta ichnoassemblage represented by Chirotherium and Isochirotherium is typical

557 for terrestrial deposits of the late Olenekian and early Anisian (Klein \& Haubold, 2007) and the

558 Gardetta chirotherian tracks correlate with the international Chirotherium barthii Assemblage

559 Zone of Klein \& Lucas (2010a). This biochron is characterized by the occurrence of

560 Chirotherium and Isochirotherium, but also by two other ichnogenera not present at Gardetta:

561 Rotodactylus, and Synaptychium. The Chirotherium barthii Assemblage Zone ranges from the

562 late Early to early Middle Triassic (late Olenekian - early Anisian), and independently confirms

563 the Early Triassic (?Olenekian) age, derived by stratigraphic correlation with other sections in

564 the Briançonnais of the Western Alps.

565 The Gardetta outcrop enlarges also the knowledge on biogeography of archosauriforms in the 566 Lower Triassic of Europe, so far based on archosaur ichnosites discovered in Italy (Val Marenca,

567 Santi et al., 2015; Sardinia, Citton et al., 2020), Spain (Moncayo and Tagamanent, Díaz-Martínez

568 \& Pérez-García, 2012), Switzerland (Cascade d'Emaney and Vieux Emosson; Cavin et al.,

569 2012), Austria (Drau Range; Krainer et al., 2012), Germany (Bundsandstein; Klein \& Haubold,

570 2007) and Poland (Wióry, Holy Cross Mountains, Klein \& Niedźwiedzki, 2012). 
Early Triassic erythrosuchid skeletal fossils are known from the late Olenekian of Russia,

572 South Africa, China and India (see Gower, 2003; Ezcurra et al., 2013, 2019, 2020; Gower et al.,

573 2014; Ezcurra, 2016). The Gardetta ichnosite suggests the presence of erythrosuchids and more

574 generally of Archosauriformes at low latitudes $\left(11.8^{\circ} \mathrm{N}\right)$ also during the Early Triassic (Fig. 11).

\section{5}

\section{Discussion and conclusions}

577 The Gardetta ichnosite is characterized by archosaur-grade footprints assigned to

578 Chirotherium isp. and to the new ichnospecies Isochirotherium gardettensis. They represent the

579 first record of terrestrial tetrapods in the Briançonnais domain of the Western Alps and expand

580 the record of archosaur-grade footprints in the Lower Triassic of Central Europe.

581 The morphological characters of the tracks assigned to Isochirotherium gardettensis suggest a

582 non-archosaurian archosauriform (Erythrosuchidae?) as possible trackmaker candidate (even

583 though the presence of crown-archosaurs cannot be excluded), thus providing crucial information

584 about continental tetrapod occurrence in Europe in the Early Triassic. Based on a phylogenetic

585 dataset made by 108 middle Permian-early Late Triassic species, Ezcurra \& Butler (2015)

586 investigate principal patterns of early archosauromorph biodiversity change across the Permo-

587 Triassic mass extinction. The study, performed using phylogenetic diversity, morphological

588 disparity, number of species and rates of phenotypic evolution across 35 million years of early

589 archosauromorph evolution, indicates consistent phylogenetic diversification of the clade in the

590 Olenekian. In particular, the early diversification of main taxa, which include erythrosuchids,

591 rhynchosaurs and tanystropheids, resulted in significantly high evolutionary rates, with a

592 diversification interpreted by the authors as a radiative response to vacant ecological space, made

593 available by the EPME (Ezcurra \& Butler, 2015). If the trackmakers' attribution for footprints 
594 here described is correct, the material from Gardetta could represent an evidence from Europe of 595 such radiation, with an archosauriform fauna composed at least by ?erythrosuchids

596 (Isochirotherium gardettensis) and pseudosuchians (Chirotherium isp.). Such clades as putative

597 trackmaker for the Gardetta tracks are consistent with an Early Triassic (likely late Early

598 Triassic) age, considering that the early history of Archosauriformes is represented essentially by

599 members of Proterosuchidae and Erythrosuchidae (Charig \& Reig, 1970; Cruickshank, 1972;

600 Charig \& Sues, 1976; Gower \& Sennikov, 2000; Gower, 2003; Ezcurra et al., 2013).

601 Following the huge Permo-Triassic biotic crisis, unfavorable environmental conditions

602 characterized much of the Early Triassic, testifying to one of the slowest recoveries for

603 ecosystems after an extinction in Earth history. A period between five and nine million years for

604 a full recovery has been proposed in several studies (Hallam, 1991; Erwin, 1992, 2001; Payne et

605 al., 2004, 2011; Algeo et al., 2011; Whiteside \& Ward, 2011), inferring a fully restored complex

606 ecosystems only at the beginning of the Middle Triassic (see Chen \& Benton, 2012). Such long

607 recovery time led to a revolution in both marine and terrestrial ecosystems (Chen \& Benton,

608 2012), with a major influence in the evolution of crucial vertebrates clades for the rest of the

609 Mesozoic and Cenozoic eras (Sepkoski, 1984; Benton, 2010). The recovery period led to the

610 emergence of totally new groups, with a rapid diversification of several lineages of eureptilians

611 both on sea and land (Nesbitt et al., 2010; Butler et al., 2011; Gower et al., 2014; Scheyer et al.,

612 2014; Motani et al., 2015a, 2015b; Peecook et al.,2018). Avemetatarsalians (which include

613 dinosaurs and pterosaurs) originated in this period (Brusatte et al., 2010; Nesbitt et al., 2010;

614 Chen \& Benton, 2012; Benton et al., 2014), along with the evolution of crucial modern group

615 ancestors, including crocodiles, lizards, turtles, frogs and mammals. All these aspects highlight 
616 the crucial importance of the Early Triassic in the ecosystems restructuring after the Permo-

617 Triassic mass extinction.

618 Retallack et al. (2011) proposed that the long recovery from the mass extinction was strongly

619 influenced by repeated greenhouse crises during the Early Triassic, with consistent negative

620 excursions in carbon isotope ratios indicating at least five greenhouse crises in the $5 \mathrm{Myr}$

621 following the EPME (Induan-Anisian) (see Kidder \& Worsley, 2004; Retallack, 2005, 2009,

622 2013; Graisby et al., 2011; Retallack et al., 2011; Sun et al., 2012; Chen \& Benton, 2012). In this

623 regard, according to Sun et al. (2012) the entire Early Triassic was characterized by temperatures

624 consistently in excess of those of the modern equatorial annual sea surface temperatures (SSTs),

625 thus exceeding a tolerable threshold for life in both oceans and on land. Inferring SSTs

626 approaching $40^{\circ} \mathrm{C}$, according to Sun et al. (2012) the temperature on land very likely fluctuated

627 to even higher levels, with terrestrial tetrapods generally absent between $30^{\circ} \mathrm{N}$ and $40^{\circ} \mathrm{S}$ in the

628 Early Triassic.

629 In this framework, and although some uncertainties on the chronological attribution persists,

630 the Gardetta ichnosite provides important evidence to the low latitude distribution of

631 archosauriforms during the Early Triassic period, soon after the PTME, corroborating the pattern

632 described by Bernardi et al. (2018) and Romano et al. (2020). In particular, the new discovery

633 provides further evidence for an early recovery terrestrial ecosystems and the presence at low

634 latitudes of archosauriformes during the Early Triassic. Such evidences support a model in which

635 the EPME did not completely vacate low-latitude lands from tetrapods that, therefore would,

636 have been able to cope with the extreme hot temperatures of Pangaea mainland. In particular, by

637 integrating both skeletal and ichnological material, recently Romano et al. (2020) restricted the 
638 "tetrapod gap" of terrestrial life in the Early Triassic to palaeolatitudes between $15^{\circ} \mathrm{N}$ and about $63931^{\circ} \mathrm{S}$.

640 According to Botha and Smith (2006), Archosauromorpha (along with Procolophonomorpha)

641 could be pre-adapted to extremely arid and hot environment conditions, considering that extant

642 reptiles rarely drink water, and are characterized by solute-linked water reabsorption

643 mechanisms, water-resistant integument and low ventilation rates (Withers, 1992; Pough et al.,

644 1996). Such physiological aspects and water conserving mechanisms, probably suggest that

645 response of the archosauriforms to the extreme hot condition of the Early Triassic (Benton,

646 2018) have probably been much more efficient and flexible than previously thought, and did not

647 necessarily imply massive dispersal towards higher latitudes as previously suggested (Sun et al., 648 2012).

649 Different anatomical features described above indicate the erythrosuchids as the most 650 probable trackmakers for the new described ichnospecies Isochirotherium gardettensis. This 651 attribution can also be supported by track parameters such a narrow trackway and high pace 652 angulation, which indicate a more upright posture with respect to a classic plesiomorphic 653 sprawling gait (see Kubo \& Benton, 2007). In particular, according to Ezcurra et al. (2013), 654 erythrosuchids were heavily built and characterized by a probably less sprawling gait, when 655 compared to the condition observed in proterosuchids. The narrow trackway, along with 656 consistently high pace angulation in the Gardetta material, also confirm the statement by Kubo \& 657 Benton (2009) that, even if proterosuchids and erythrosuchids are traditionally considered as 658 sprawlers, ichnological evidences indicate that archosaurian erect-limb locomotion already 659 evolved in the Early Triassic; the latter conclusion is also supported by ghost ranges from 
660 cladograms (Sereno, 1991; Benton, 1999), and fragmentary materials from Russia (Gower \& 661 Sennikov, 2000).

662 To date, erythrosuchids are totally unknown from North America and Europe, being described 663 only from Russia, South Africa, China and India (see Gower, 2003; Ezcurra et al., 2013, 2019, 664 2020; Gower et al., 2014; Ezcurra, 2016). Thus, the material from the Lower Triassic deposits of 665 Gardetta could represent the first occurrence of the clade in Europe, although, as already pointed 666 out, the attribution is for the moment only tentative and new studies are underway to better 667 constrain the identity of the zoological trackmaker.

668 The planned future excavations in the Gardetta ichnosite will hopefully provide additional 669 data to improve our knowledge of the evolutionary history of Archosauriformes in the aftermath 670 of the EPME.

671

MGPT-PU Museo di Geologia e Paleontologia dell’Università di Torino, Italy)

674

675

\section{ACKNOWLEDGMENTS}

677 We warmly thank the Associazione Escarton that generously supported by this research during 678 the field campaigns held in 2009, 2017 and 2018. We thank the reviewers Ignacio Díaz679 Martínez, Heitor Francischini, Martin Lockley and the Editor Graciela Piñeiro for their 680 corrections and suggestions that greatly improved the manuscript. A special thanks to Giovanni 681 Raggi for his valuable and constant support during the field works and the project organisation. 682 We acknowledge insightful discussions with A. d'Atri (University of Torino). The authors wish 
683 also to thank Dr. Debora Rocchietti and Dr. Alberto Crosetto (Soprintendenza Archeologia Belle 684 Arti e Paesaggio per le province di Alessandria, Asti e Cuneo) and Dr. Attilio Dalmasso (Museo 685 dei fossili in San Rocco di Bernezzo) for their assistance. Fabio Manucci is thanked for video 686 production and artwork. Finally, a special thank is also due to Hanna Luginbühl for her help in 687 mapping 2009 and to Cecilia Gomiero, Jacopo Valori and Nicolò Amoruso for their precious 688 help during 2018 fieldwork. This is the publication number 349 of the Museo di Geologia e 689 Paleontologia collections at the Università degli Studi di Torino.

690

691

\section{REFERENCES}

692

693

694

695

696

697

698

699

700

701

702

703

704

705

Algeo TJ, Chen ZQ, Fraiser ML, Twitchett RJ. 2011. Terrestrial-marine teleconnections in the collapse and rebuilding of Early Triassic marine ecosystems. Palaeogeography, Palaeoclimatology, Palaeoecology 308(1-2):1-11.

Alroy J. 2003. Global databases will yield reliable measures of global biodiversity. Paleobiology 29(1):26-29.

Avanzini M, Cavin L. 2009. A new Isochirotherium trackway from the Triassic of Vieux Emosson, SW Switzerland: stratigraphic implications. Swiss Journal of Geosciences 102:353361.

Avanzini M, Leonardi G. 2002. Isochirotherium inferni ichnosp. n. in the upper Anisian (Illyrian) of Adige Valley (bozen, Italy). Bollettino della Società Paleontologica Italiana 41:41-50.

Avanzini M, Lockley M. 2002. Middle Triassic archosaur population structure: interpretation based on Isochirotherium delicatum fossil footprints (Southern Alps, Italy). Palaeogeography, Palaeoclimatology, Palaeoecology, 185(3-4): 391-402. 
706

707

708

709

710

711

712

713

714

715

716

717

718

719

720

721

722

723

724

725

726

727

Avanzini M, Mietto P. 2008. Lower and Middle Triassic footprint-based biochronology in the Italian Southern Alps. Oryctos 8:3-13.

Baird D. 1954. Chirotherium lulli, a pseudosuchian reptile from New Jersey. Museum of Comparative Zoology Bulletin 111:165-192.

Baud A. 1976. Les terriers de Crustacés décapodes et l'origine de certains facies du Trias carbonaté. Eclogae Geologicae Helvetiae 69(2):415-424.

Baud A, Plasencia P, Hirsch F, Richoz S. 2016. Revised middle Triassic stratigraphy of the Swiss Prealps based on conodonts and correlation to the Briançonnais (Western Alps). Swiss Journal of Geosciences 109:365-377.

Belvedere M, Farlow J.O. 2016. A numerical scale for quantifying the quality of preservation of vertebrate tracks. In: Falkingham PL, Marty D, Richter A (eds.), Dinosaur Tracks: The Next Steps, Indiana University Press, Bloomington, pp. 92-98.Benton MJ. 1999. Scleromochlus taylori and the origin of dinosaurs and pterosaurs. Philosophical Transactions of the Royal Society of London. Series B: Biological Sciences 354(1388):1423-1446.

Benton MJ. 2003. When life nearly died: the greatest mass extinction of all time. Thames \& Hudson, London.

Benton MJ. 2010. The origins of modern biodiversity on land. Philosophical Transactions of the Royal Society B: Biological Sciences 365(1558):3667-3679.

Benton MJ. 2018. Hyperthermal-driven mass extinctions: killing models during the PermianTriassic mass extinction. Philosophical Transactions of the Royal Society A 376:20170076.

Benton M, Newell AJ. 2014. Impacts of global warming on Permo-Triassic terrestrial ecosystems. Gondwana Research 25:1308-1337. 
728 Benton MJ, Twitchett RJ. 2003. How to kill (almost) all life: the end-Permian extinction event.

$729 \quad$ Trends in Ecology \& Evolution 18:358-365.

730 Benton MJ, Forth J, Langer MC. 2014. Models for the rise of the dinosaurs. Current Biology

$731 \quad 24:$ R87-R95.

732 Bernardi M, Petti FM, Benton MJ. 2018. Tetrapod distribution and temperature rise during the

733 Permian- Triassic mass extinction. Proceedings of the Royal Society of London B

$734 \quad$ 285:20172331.

735

736

737

738

739

740

741

742

743

744

745

746

747

748

749

750

Bernardi M, Klein H, Petti FM, Ezcurra MD. 2015. The Origin and Early Radiation of Archosauriforms: Integrating the Skeletal and Footprint Record. PLoSONE 10(6):e0128449.

Berner RA. 2002. Examination of hypotheses for the Permo-Triassic boundary extinction by carbon cycle modeling. Proceedings of the National Academy of Sciences, U.S.A. 99:41724177.

Bertok C, Martire L, Perotti E, d'Atri A, Piana F. 2012. Kilometre-scale palaeoescarpments as evidence for Cretaceous synsedimentary tectonics in the External Briançonnais Domain (Ligurian Alps, Italy). Sedimentary Geology 251:58-75.

Botha J, Smith RMH. 2006. Rapid vertebrate recuperation in the Karoo Basin of South Africa following the end-Permian extinction. Journal of African Earth Sciences 45:502-514.

Broom R. 1903. On a new reptile (Proterosuchus fergusi) from the Karroo beds of Tarkastad, South Africa. Annals of the South African Museum 4:159-164.

Broom R. 1905. Notice of some new reptiles from the Karoo Beds of South Africa. Records of the Albany Museum 1:331-337.

Broom R. 1913. Note on Mesosuchus browni, Watson, and on a new South African Triassic pseudosuchian (Euparkeria capensis). Records of the Albany Museum 2: 394-396. 
751 Brusatte SL, Benton MJ, Desojo JB, Langer MC. 2010. The higher-level phylogeny of

752 Archosauria (Tetrapoda: Diapsida). Journal of Systematic Palaeontology 8(1):3-47.

753 Butler RJ, Brusatte SL, Reich M, Nesbitt SJ, Schoch RR, Hornung JJ. 2011. The sail-

754 backed reptile Ctenosauriscus from the latest Early Triassic of Germany and the timing and

755 biogeography of the early archosaur radiation. PloS ONE 6(10):e25693.

756 Caby R, Galli J. 1964. Existence de cinérites et tufs volcaniques dans le Trias moyen de la zone

757 briançonnaise. Comptes Rendus de l'Académie des Sciences de Paris 259:417-420.

758 Carrano MT, Wilson JA. 2001. Taxon distributions and the tetrapod track record. Paleobiology $759 \quad 27(3): 564-582$.

760

761

762

763

764

765

766

767

768

769

770

771

772

Carraro F, Dal Piaz GV, Franceschetti B, Malaroda R, Sturani C, Zanella E. 1970. Carta

Geologica del massiccio dell'Argentera alla scala 1: 50.000 e Note Illustrative. Memorie della Società Geologica Italiana 9:557-663.

Cassinis G, Perotti C, Santi G. 2018. Post-Variscan Verrucano-like deposits in Italy, and the onset of the alpine tectono-sedimentary cycle. Earth-Science Reviews 185:476-497.

Cavin L, Avanzini M, Bernardi M, Piuz A, Proz PA, Meister C, Boissonnas J, Meyer CA. 2012. New vertebrate trackways from the autochthonous cover of the Aiguilles Rouges Massif and reevaluation of the dinosaur record in the Valais, SW Switzerland. Swiss Journal of Palaeontology 131:317-324.

Charig AJ, Reig OA. 1970. The classification of the Proterosuchia. Biological Journal of the Linnean Society 2(2):125-171.

Charig AJ, Sues H-D. 1976. Proterosuchia. In: Kuhn, O. (ed.) Handbuch der Paläoherpetologie 13. Gustav Fischer, Stuttgart, 11-39. 
773 Chatterjee S. 1985. Postosuchus, a new thecodontian reptile from the Triassic of Texas and the

774 origin of tyrannosaurs. Philosophical Transactions of the Royal Society of London B 309:395-

775460.

776 Chen ZQ, Benton MJ. 2012. The timing and pattern of biotic recovery following the end-

777 Permian mass extinction. Nature Geoscience 5(6):375-383.

778 Citton P, Ronchi A, Nicosia U, Sacchi E, Maganuco S, Cipriani A, Innamorati G, Zuccari

779 C, Manucci F, Romano M. 2020. Tetrapod tracks from the Middle Triassic of NW Sardinia

780 (Nurra region, Italy). Italian Journal of Geosciences 139(2):309-320.

781 Costamagna LG. 2013. Middle Triassic carbonate lithostratigraphy of the Southern

782 Briançonnais (Cottian Alps, Italy) and comparison with the surrounding areas. GeoActa 12:1-

78324.

784 Costamagna LG, Barca S, Nervo R. 2002. Analisi di facies della successione carbonatica

785 mediotriassica del Dominio Brianzonese fra le valli Stura e Maira (Alpi Occidentali, Cuneo,

786 Italia): La sezione del Vallone del Preit. In: Fioraso G., Malusà M., Mosca P. \& Tallone S.

787 (eds.) - 81 ${ }^{\text {a }}$ Riunione estiva SGI, Riassunti delle Comunicazioni orali e dei poster: 110-111,

788 Torino.

789 Courel L, Demathieu G. 1976. Une ichnofaune reptilienne remarquable dans les grès Triasique

790 de Largentière (Ardèche, France). Palaeontogr. A 151: 194-216.

791 Courel L, Demathieu G, Gall JC. 1979. Figures sédimentaires et traces d'origine biologique du

792 Trias moyen de la bordure orientale du Massif Central. Signification sédimentologique et

793 paleoécologique. Geobios 12: 379-397.

794 Cruickshank ARI. 1972. The proterosuchian thecodonts. In: Joysey, K. A. \& Kemp, T. S. (eds)

795 Studies in Vertebrate Evolution. Oliver and Boyd, Edinburgh, 89-119. 
796 Cruickshank ARI. 1978. The pes of Eythrosuchus africanus Broom. Zoological Journal of the 797 Linnean Society 62:161-177.

798

799

800

801

802

803

804

805

806

807

808

809

810

811

812

813

814

815

816

817

d'Atri A, Piana F, Barale L, Bertok C, Martire L. 2016. Geological setting of the southern termination of Western Alps. International Journal of Earth Sciences 105(6):1831-1858.

Decarlis A, Lualdi A. 2009. A sequence stratigraphic approach to a Middle Triassic shelf-slope complex of the Ligurian Alps (Ligurian Briançonnais, Monte Carmo-Rialto unit, Italy). Facies 55:267-290.

Decarlis A, Dallagiovanna G, Lualdi A, Maino M, Seno S. 2013. Stratigraphic evolution in the Ligurian Alps between Variscan heritages and the Alpine Tethys opening: A review. EarthScience Reviews 125:43-68.

Decarlis A, Manatschal G, Haupert I, Masini E 2015. The tectono-stratigraphic evolution of distal, hyper-extended magma-poor conjugate rifted margins: Examples from the Alpine Tethys and Newfoundland-Iberia. Marine and Petroleum Geology 68:54-72.

Demathieu G. 1970. Les empreintes de pas de vertébrés du Trias de la bordure Nord-Est du Massif Central. Cahiers de Paléontologie CRNS Paris, 211 p.

Demathieu G. 1984. Une ichnofaune du Trias moyen du basin de Lodève (Hérault, France). Ann. Paleontol. (Vertebr.-Invertebr.) 70: 247-273.

Demathieu G, Weidmann M. 1982. Les empreintes de pas de reptiles dans le Trias du Vieux Emosson (Finhaut, Valais, Suisse). Eclogae Geologicae Helvetiae 75:721-757.

Díaz-Martínez I, Pérez-García A. 2012. Historical and comparative study of the first Spanish vertebrate paleoichnological record and bibliographic review of the Spanish chirotheriid footprints. Ichnos, 19(3): 141-149.

Peer) reviewing PDF | (2020:08:51782:4:0:NEW 15 Nov 2020) 
818 Dìaz-Martinez I, Castanera D, Gasca JM, Canudo JI. 2015. A reappraisal of the Middle

819 Triassic chirotheriid Chirotherium ibericus Navas, 1906 (Iberian Range, NE Spain), with

820 comments on the Triassic tetrapod track biochronology of the Iberian Peninsula. PeerJ

$821 \quad 3: 1044$.

822 Diedrich C. 2015. Isochirotherium trackways, their possible trackmakers (?Arizonasaurus):

823 intercontinental giant archosaur migrations in the Middle Triassic tsunami-influenced

824 carbonate intertidal mud flats of the European Germanic Basin. Carbonates and Evaporites

$825 \quad 30: 229-252$.

826 Egerton PG. 1839. On two casts in sandstone of impression of the Hind Foot of a gigantic

827 Cheirotherium, from the New red sandstone of Cheshire. The London and Edinburgh

828 Philosophical Magazine and Journal of Science, 3rd series 14(75):151-158.

829 Erwin DH. 1992. A preliminary classification of evolutionary radiations. Historical Biology

$830 \quad 6: 133-147$.

831 Erwin DH. 1993. The Great Paleozoic Crisis, Life and Death in the Permian. Colombia

832 University Press, New York, 327 pp.

833 Erwin DH. 2001. Lessons from the past: biotic recoveries from mass extinctions. Proceedings of

834 the National Academy of Sciences 98(10):5399-5403.

835 Evans SE, Wang Y. 2005. Dalinghosaurus, a lizard from the Early Cretaceous Jehol Biota of

836 north- east China. Acta Paleontologica Polonica 50:725-742.

837 Ezcurra MD. 2016. The phylogenetic relationships of basal archosauromorphs, with an 838 emphasis on the systematics of proterosuchian archosauriforms. PeerJ 4:e1778. 
839 Ezcurra MD, Butler RJ. 2015. Taxonomy of the proterosuchid archosauriforms (Diapsida:

840 Archosauromorpha) from the earliest Triassic of South Africa, and implications for the early

841 archosauriform radiation. Palaeontology 58(1):141-170.

842 Ezcurra MD, Butler RJ, Gower DJ. 2013. 'Proterosuchia': the origin and early history of 843 Archosauriformes. Geological Society, London, Special Publications 379(1):9-33.

844 Ezcurra MD, Gower DJ, Sennikov AG, Butler RJ. 2019. The osteology of the holotype of the 845 early erythrosuchid Garjainia prima Ochev, 1958 (Diapsida: Archosauromorpha) from the 846 upper Lower Triassic of European Russia. Zoological Journal of the Linnean Society 185:717-783.

848

Ezcurra MD, Jones AS, Gentil AR, Butler RJ. 2020. Early Archosauromorphs: The Crocodile and Dinosaur Precursors. Encyclopedia of Geology, 2nd edition.

Feldmann M, Furrer H, Glarus K. 2009. Die Saurierspuren am Tödi und ihre geologische Umgebung. Mitteilungen der Naturforschenden Gesellschaft des Kantons Glarus 18:28-37.

Fortuny J, Bolet A, Selles AG, Cartanya J, Galobart A. 2011. New insights on the Permian and Triassic vertebrates from the Iberian peninsula with emphasis on the Pyrenean and Catalonian basins. Journal of Iberian Geology 37(1):65-86.

Gand G. 1978. Interprètations palèontologique et palèoècologique d'un sixième assamblage à traces de reptiles des carrières triasiques de St.-Sernin-du Bois (Autunois, France). Conclusions gènèrales à ètude du gisement. Bulletin de la Société d'Historie Naturelle d'Autun 87: 9-29.

Gand G. 1979. Description de deux nouvelles traces d'Isochirotherium observées dans les grès du Trias moyen de Bourgogne. Bull. Soc. Hist. Nat. Creusot 37: 13-25. 
861 Gidon M. 1958a. Nouvelles observations sur la zone briançonnaise au delà de la frontiére 862 franco-italienne (Bassin de la Haute Maira, Province de Cuneo). Trav. Lab. Géol. Univ. 863 Grenoble 34:153-167.

864 Gidon M. 1958b. La Zone Briançonnaise en Haute Ubaye (Basses-Alpes) et son prolongement 865 au Sud-Est. PhD Thesis. Faculté des Sciences de l'Université de Grenoble, 272 pp.

866 Gidon M. 1972. Les chainons briançonnais et subbriançonnais de la rive gauche de la Stura 867 entre la Val de l'Arma (province de Cuneo-Italie). Géologie Alpine 48(1):87-120.

868 Gidon M. 1978. Carte géologique détaillée de la France à l'échelle 1/50.000, feuille Larche, $1^{\circ}$ 869 édition. Bureau de Recherche Géologique et Minière, Orléans, with explanatory notes, pp. 187028.

871 Golden Software 2002. Surfer version 8.0: surface mapping system.

872 Gottmann-Quesada A, Sander PM. 2009. A redescription of the early archosauromorph 873 Protorosaurus speneri Meyer, 1832 and its phylogenetic relationships. Palaeontographica $874 \quad$ Abteilung A 287:123-220.

875 Gower DJ. 1996. The tarsus of erythrosuchid archosaurs, and implications for early diapsid 876 phylogeny. Zoological Journal of the Linnean Society 116(4):347-375.

877 Gower DJ. 2003. Osteology of the early archosaurian reptile Erythrosuchus africanus Broom. 878 Annals of the South African Museum 110:1-88.

879 Gower DJ, Sennikov AG. 2000. Early Archosaurs from Russia. In: Benton MJ, Shishkin MA, 880 Unwin DM, Kurochkin EN, editors. The Age of Dinosaurs in Russia and Mongolia. 881 Cambridge University Press, Cambridge. pp. 140-159. 
882 Gower DJ, Hancox PJ, Botha-Brink J, Sennikov AG, Butler RJ. 2014. A new species of 883 Garjainia Ochev, 1958 (Diapsida: Archosauriformes: Erythrosuchidae) from the Early $884 \quad$ Triassic of South Africa. PLoS One 9(11):e111154.

885 Grasby SE, Sanei H, Beauchamp B. 2011. Catastrophic dispersion of coal fly ash into oceans 886 during the latest Permian extinction. Nature Geoscience 4(2): 104.

887 Hallam A. 1991. Why was there a delayed radiation after the end-Palaeozoic extinctions? 888 Historical Biology 5(2-4):257-262.

889 Haubold H. 1967. Eine Pseudosuchier- Fährtenfauna aus dem buntsandstein südthüringens. $890 \quad$ Hallesches Jahrbuch für Mitteldeutsche Erdgeschichte 8:12-48.

891

892

893

894

895

896

897

898

899

900

901

902

903

904

Haubold H. 1971a. Die Tetrapodenfährten des Buntsandsteins. Paläontologische Abhandlungen A 4(3):395-548.

Haubold H. 1971b. Ichnia Amphibiorum et Reptiliorum fossilium. Encyclopedia of

$$
\text { Paleoherpetology 18:1-124. }
$$

Haubold H. 1984. Saurierfährten. Wittenberg, Ziemsen, 231 p.

Haubold H. 1986. Archosaur footprints at the terrestrial Triassic-Jurassic transition. 190-201.

In Padian K. (ed.). The beginning of the Age of Dinosaurs: Faunal change across the TriassicJurassic boundary. Cambridge University Press, Cambridge, 378 pp.

Haubold H. 2006. Die Saurierfährten Chirotherium barthii Kaup, 1835—das Typusmaterial aus dem Buntsandstein bei Hildburghausen/Thüringen und das Chirotherium-Monument. Veröffentlichungen Naturhistorisches Museum Schleusingen 21:3-31.

Haubold H, Klein H. 2002. Chirotherien und Grallatoriden aus der Unteren bis Oberen Trias Mitteleuropas und die Entstehung der Dinosauria. Hallesches Jahrbuch für Geowissenschaften B 24:1-22. 
905 Huene F. von 1902. Übersichtüber die Reptilien der Trias. Geologische und Paläontologische 906 Abhandlungen 10:1-84.

907 Joachimski MM, Lai X, Shen S, Jiang H, Luo G, Chen B, Chen J, Sun Y. 2012. Climate 908 warming in the latest Permian and the Permian-Triassic mass extinction. Geology 40:195$909 \quad 198$.

910 Kaup JJ. 1835. Über Tierfährten bei Hildburghausen. Neues Jahrbuch für Mineralogie, 911 Geologie und Paläontologie 1835, 327-328.

912 Kidder DL, Worsley TR. 2004. Causes and consequences of extreme Permo-Triassic warming 913 to globally equable climate and relation to the Permo-Triassic extinction and recovery.

914 Palaeogeography, Palaeoclimatology, Palaeoecology 203(3-4):207-237.

915 King MJ, Sarjeant WAS, Thompson DB, Tresise G. 2005. A revised systematic

916 ichnotaxonomy and review of the vertebrate footprint ichnofamily Chirotheriidae from the $917 \quad$ British Triassic. Ichnos 12:241-299.

918 Klein H, Lucas SG. 2010a. Tetrapod footprints and their use in biostratigraphy and

919 biochronology of the Triassic. In Lucas, S.G. (ed.), The Triassic timescale. Geological Society $920 \quad$ of London Special Publications 334:419-446.

921 Klein H, Lucas SG. 2010b. Review of the tetrapod ichnofauna of the Moenkopi

922 Formation/Group (Early-Middle Triassic) of the American Southwest. New Mexico Museum 923 of Natural History and Science Bulletin 50:1-67.

924 Klein H, Niedźwiedzki G. 2012. Revision of the Lower Triassic tetrapod ichnofauna from 925 Wióry, Holy Cross Mountains, Poland. New Mexico Museum of Natural History and Science, 926 Bulletin 56:1-62. 
927 Klein H, Haubold H. 2007. Archosaur footprints-potential for biochronology of Triassic 928 continental sequences. New Mexico Museum of Natural History and Science Bulletin 41:120929130.

930 Klein H, Voigt S, Hminna A, Saber H, Schneider J, Hmich D. 2010. Early Triassic archosaur931 dominated footprint assemblage from the Argana Basin (western High Atlas, Morocco). 932 Ichnos 17(3):215-227.

Klein H, Voigt S, Saber H, Schneider JW, Hminna A, Fischer J, Lagnaoui A, Brosig A.

Kubo T, Benton MJ. 2007. Evolution of hindlimb posture in archosaurs: limb stresses in extinct

Kubo T, Benton MJ. 2009. Tetrapod postural shift estimated from Permian and Triassic 
950

951

952

953

954

955

956

957

958

959

960

961

962

963

964

965

966

967

968

969

970

971

trackways. Palaeontology 52(5):1029-1037.

Lautenschlager S, Desojo JB. 2011. Reassessment of the Middle Triassic rauisuchian archosaurs Ticinosuchus ferox and Stagonosuchus nyassicus. Paläontologische Zeitschrift 85(4): $357-381$.

Leonardi G. 1987. Glossary and manual of tetrapod footprint palaeoichnology. p.p. 117. Brasilia: Ministerio das Minas e Energia Departamento Nacional da Producao Mineral.

Lorenzoni S, Zanettin E. 1958. Contributo alla conoscenza del giacimento uranifero di Preit (Alpi Cozie). Studi e Ricerche Divisione Geomineraria CNRN 1(2):349-433.

Lualdi A, Bianchi U. 1990. La Formazione di Costa Losera: una nuova unità stratigrafica dell’Anisico delle Alpi Liguri. Atti Ticinensi di Scienze della Terra 33:33-62.

Lualdi A, Seno S. 1984. Osservazioni stratigrafiche e tettoniche nella zona dei Rio di Nava (Brianzonese Ligure Esterno, Unità di Ormea). Memorie della Società Geologica Italiana 28:493-503.

Malaroda R. 1970. Carta geologica del Massiccio dell'Argentera alla scala 1: 50.000. Allegato al vol. 9 delle Memorie della Società Geologica Italiana.

Mallison H, Wings O. 2014. Photogrammetry in paleontology-a practical guide. Journal of Paleontological Techniques 12:1-31.

Manning PL. 2004. A new approach to the analysis and interpretation of tracks: examples from the dinosauria. Geological Society, London, Special Publications, 228(1): 93-123.

Megard-Galli J, Baud A. 1977. Le Trias moyen et supérieur des Alpes nord-occidentales et occidentales: données nouvelles et corrélations stratigraphiques. Bulletin B.R.G.M. 4(3):233250. 
972 Melchor RN, De Valais S. 2006. A review of Triassic tetrapod track assemblages from 973 Argentina. Palaeontology 49(2):355-379.

974 Motani R, Jiang DY, Chen GB, Tintori A, Rieppel O, Ji C, Huang JD. 2015a. A basal

975 ichthyosauriform with a short snout from the Lower Triassic of China. Nature 517(7535):485-

$976 \quad 488$.

977 Motani R, Jiang DY, Tintori A, Rieppel O, Chen GB, You H. 2015b. Status of Chaohusaurus 978 chaoxianensis (Chen, 1985). Journal of Vertebrate Paleontology 35(1):e892011.

979 Nesbitt SJ. 2011. The early evolution of archosaurs: relationships and the origin of major clades. 980 Bulletin of the American Museum of Natural History 41(supp.):1-292.

981 Nesbitt SJ, Liu J, Li C. 2010. A sail-backed suchian from the Heshanggou Formation (Early 982 Triassic: Olenekian) of China. Earth and Environmental Science Transactions of the Royal 983 Society of Edinburgh 101:271-284.

984 Olsen PE. 1995. A new approach for recognizing track makers. Geological Society of America, 985 Abstracts with Programs 27:72.

986 Olsen PE, Smith JB, McDonald NG. 1998. Typematerial of the type species of the classic 987 theropod footprint genera Eubrontes, Anchisauripus and Grallator (Early Jurassic, Hartford 988 and Deerfield basins, Connecticut and Massachusetts, U.S.A.). J. Vertebr. Paleontol. 18: 586989601.

Payne JL, Lehrmann DJ, Wei J, Orchard MJ, Schrag DP, Knoll AH. 2004. Large

991 perturbations of the carbon cycle during recovery from the end-Permian extinction. Science $992 \quad 305: 506-509$.

993 Payne JL, Summers M, Rego BL, Altiner D, Wei J, Yu M, Lehrmann DJ. 2011. Early and 994 Middle Triassic trends in diversity, evenness, and size of foraminifers on a carbonate platform 
995

996

997

998

999

1000

1001

1002

1003

1004

1005

1006

1007

1008

1009

1010

1011

1012

1013

1014

1015

1016

1017

in south China: implications for tempo and mode of biotic recovery from the end-Permian mass extinction. Paleobiology 37:409-425.

Peabody FE. 1948. Reptile and amphibian trackways from the Lower Triassic Moenkopi

$$
\text { formation of Arizona and Utah. Bulletin of the Department of Geological sciences 27:295- }
$$
468.

Peecook BR, Smith RM, Sidor CA. 2018. A novel archosauromorph from Antarctica and an updated review of a high-latitude vertebrate assemblage in the wake of the end-Permian mass extinction. Journal of Vertebrate Paleontology 38(6):e1536664.

\section{Petti FM, Avanzini M, Belvedere M, De Gasperi M, Ferretti P, Girardi S, Remondino F,} Tomasoni R. 2008. Digital 3D modelling of dinosaur footprints by photogrammetry and laser scanning techniques: integrated approach at the Coste dell'Anglone tracksite (Lower Jurassic, Southern Alps, Northern Italy). Studi Trentini di Scienze Naturali, Acta Geologica 83:303-

\section{5.}

Petti FM, Bernardi M, Kustatscher E, Renesto S, Avanzini M. 2013. Diversity of continental tetrapods and plants in the Triassic of the Southern Alps: Ichnological, paleozoological and paleobotanical evidence. In Tanner, L.H., Spielmann, J.A. and Lucas, S.G. (eds.), The Triassic System. New Mexico Museum of Natural History and Science, Bulletin 61:458-484.

Peyer K, Carter JG, Sues H-D, Novak SE, Olsen PE. 2008. A new suchian archosaur from the Upper Triassic of North Carolina. Journal of Vertebrate Paleontology 28:363-381.

Pough FH, Heiser JB, McFarland WN. 1996. Vertebrate Life. Prentice Hall International, New Jersey.

Racki G. 2003. End-Permian mass extinction: oceanographic consequences of double catastrophic volcanism. Lethaia 35:171-173. 
1018 Racki G, Wignall PB. 2005. Late Permian double-phased mass extinction and volcanism: an 1019 oceanographic perspective. In: Over, D.J., Morrow, J.R., Wignall, P.B. (Eds.), Understanding 1020 Late Devonian and Permian-Triassic Biotic and Climatic Events: Towards an Integrated 1021 Approach. Elsevier B.V., pp. 263-297.

1022

1023

1024

1025

1026

1027

1028

1029

1030

1031

1032

1033

1034

1035

1036

1037

1038

1039

1040

Remondino F, Rizzi A, Girardi S, Petti FM, Avanzini M. 2010. 3D Ichnology-recovering digital 3D models of dinosaur footprints. The Photogrammetric Record 25(131):266-282.

Retallack GJ. 2005. Permian greenhouse crises. The nonmarine Permian. New Mexico Museum of Natural History and Science Bulletin 30:256-269.

Retallack GJ. 2009. Greenhouse crises of the past 300 million years. Geological Society of America Bulletin 121(9-10):1441-1455.

Retallack GJ. 2013. Permian and Triassic greenhouse crises. Gondwana Research 24(1):90-103.

Retallack GJ, Jahren AH. 2008. Methane release from igneous intrusion of coal during Late Permian extinction events. The Journal of Geology 116:1-20.

Retallack GJ, Sheldon ND, Carr PF, Fanning M, Thompson CA, Williams ML, Jones BG, Hutton A. 2011. Multiple Early Triassic greenhouse crises impeded recovery from Late Permian mass extinction. Palaeogeography, Palaeoclimatology, Palaeoecology 308(12):233-251.

Romano M, Bernardi M, Petti FM, Rubidge B, Hancox J, Benton MJ. 2020. Early Triassic terrestrial tetrapod fauna: a review. Earth-Science Reviews, https://doi.org/10.1016/j.earscirev.2020.103331.

Romano M, Citton P, Nicosia U. 2015. Corroborating trackmaker identification through footprint functional analysis: the case study of Ichniotherium and Dimetropus. Lethaia 49:102-116. 
1041 Romer AS. 1971. The Chanares (Argentina) Triassic reptile fauna XI. Two new long-snouted 1042 thecodonts, Chanaresuchus and Gualosuchus. Breviora 379:1-22.

1043 Santi G, Lualdi A, Decarlis A, Nicosia U, Ronchi A. 2015. Chirotheriid footprints from the 1044 Lower-Middle Triassic of the Briançonnais Domain (Pelite di Case Valmarenca, Western 1045 Liguria, NW Italy). Bollettino della Società Paleontologica Italiana 54(2):82.

1046 Scheyer TM, Romano C, Jenks J, Bucher H. 2014. Early Triassic marine biotic recovery: the 1047 predators' perspective. PLOS ONE 9:e88987.

1048 Sephton MA, Looy CV, Brinkhuis H, Wignall PB, de Leeuw JW, Visscher H. 2005.

1049 Catastrophic soil erosion during the end-Permian biotic crisis. Geology 33:941-944.

1050 Sereno PC. 1991. Basal archosaurs: phylogenetic relationship and functional implications. 1051 Journal of Vertebrate Paleontology 11:1-53.

1052

1053

1054

1055

1056

1057

1058

1059

1060

1061

1062

1063

\section{Shen J, Chen J, Algeo TJ, Yuan S, Feng Q, Yu J, Zhou L, O’Connell B, Planavsky NJ.} 2019. Evidence for a prolonged Permian-Triassic extinction interval from global marine mercury records. Nature communications 10(1):1563.

Schmid SM, Fügenschuh B, Kissling E, Schuster R. 2004. Tectonic map and overall architecture of the Alpine orogen. Eclogae Geologicae Helvetiae 97:93-117.

Schmid SM, Kissling E, Diehl T, van Hinsbergen DJJ, Molli G. 2017. Ivrea mantle wedge, arc of the Western Alps, and kinematic evolution of the Alps - Apennines orogenic system. Swiss Journal of Geosciences 110:581-612.

Schobben M, Joachimski MM, Korn D, Leda L, Korte C. 2014. Palaeotethys seawater temperature rise and an intensified hydrological cycle following the end-Permian mass extinction. Gondwana Research 26:675-683.

Schoch RR, Sues HD. 2014. A new archosauriform reptile from the Middle Triassic (Ladinian) 
1064

1065

1066

1067

1068

1069

1070

1071

1072

1073

1074

1075

1076

1077

1078

1079

1080

1081

1082

1083

1084

1085

1086

of Germany. Journal of Systematic Palaeontology, 12(1):113-131.

Sepkoski JJ Jr. 1984. A kinetic model of Phanerozoic taxonomic diversity. III. Post-Paleozoic families and mass extinctions. Paleobiology 10:246-267.

Smith RMH, Evans SE. 1996. New material of Youngina: evidence of juvenile aggregation in Permian diapsid reptiles. Palaeontology 39:289-303.

Song H, Wignall PB, Tong J, Yin H. 2013. Two pulses of extinction during the PermianTriassic crisis. Nature Geoscience 6(1):52.

Song H, Wignall PB, Tong J, Song H, Chen J, Chu D, ... Lai X. 2015. Integrated Sr isotope variations and global environmental changes through the Late Permian to early Late Triassic. Earth and Planetary Science Letters 424:140-147.

Sookias RB, Butler RJ. 2013. Euparkeriidae. Geological Society, London, Special Publications 379:35-48.

Sues HD, Desojo JB, Ezcurra MD. 2013. Doswelliidae: a clade of unusual armoured archosauriforms from the Middle and Late Triassic. Geological Society, London, Special Publications 379:SP379-13.

Sun Y, Joachimski M, Wignall PB, Yan C, Chen Y, Jiang H, Wang L, Lai X. 2012. Lethally Hot Temperatures During the Early Triassic Greenhouse. Science 338:1-35.

Torsvik TH, Van Der Voo R, Preeden U, Mac C, Steinberger B, Doubrovine PV, van Hinsbergen DJJ, Domeier M, Gaina C, Tohver E, Meert JG, McCausland PJA, Cocks

LRM. 2012. Earth-Science Reviews Phanerozoic polar wander, palaeogeography and dynamics. Earth Science Reviews 114(3-4):325-368.

Treasise G, Sarjeant WAS. 1997. The tracks of Triassic Vertebrates. Fossil Evidence from North-West England. The stationery Office, London, 204 pp. 
1087 Trotteyn MJ, Arcucci AB, Raugust T. 2013. Proterochampsia: an endemic archosauriform

1088 clade from South America. In: Anatomy, Phylogeny and Palaeobiology of Early Archosaurs

1089 and their Kin (eds Nesbitt S.J., Desojo J.B., Irmis R.B.), Geological Society, London, Special

$1090 \quad$ Publications 379:59-90.

1091

1092

1093

1094

1095

1096

1097

1098

1099

1100

1101

1102

1103

1104

1105

1106

1107

1108

1109

\section{Van Hinsbergen DJJ, De Groot LV, Van Schaik SJ, Spakman W, Bijl PK, Sluijs A,}

Langereis CG, Brinkhuis H. 2015. A paleolatitude calculator for paleoclimate studies. PLoS ONE 10(6):1-21.

Vanossi M. 1969. La serie brianzonese di Salto del Lupo (Liguria Occ.): osservazioni sedimentologico-stratigrafiche. Atti Ist. Geol. Univ. Pavia 20: 3-16.

Vanossi M. 1974. L'Unità di Ormea: una chiave per l'interpretazione del Brianzonese ligure. Tipografia del libro.

Vanossi M. 1991. Guide Geologiche Regionali, 11 itinerari, Alpi Liguri (a cura della SGI), 296 pp. BE-MA Edit., Milano.

Welles SP. 1947. Vertebrates from the Upper Moenkopi Formation of Northern Arizona. University of California Publications in Geological Science 27:241-294.

Whiteside JH, Ward PD. 2011. Ammonoid diversity and disparity track episodes of chaotic carbon cycling during the early Mesozoic. Geology 39:99-102.

Wignall PR. 2001. Large igneous provinces and mass extinctions. Earth-Science Reviews 53:133.

Wilson JA 2005. Integrating ichnofossil and body fossil records to estimate locomotor posture and spatiotemporal distribution of early sauropod dinosaurs: a stratocladistic approach. Paleobiology 31(3): 400-423.

Withers PC. 1992. Comparative Animal Physiology. Saunders College, New York. 
1110

1111

1112

1113

1114

1115

1116

1117

1118

1119

1120

1121

1122

1123

1124

1125

1126

1127

1128

1129

1130

1131

Xing LD, Klein H, Lockley MG, Li J, Zhang J, Matsukawa M, Xiao J. 2013. Chirotherium trackways from the Middle Triassic of Guizhou, China. Ichnos 20:99-107.

Young CC. 1964. The pseudosuchians in China. Palaeontologia Sinica Series C 19:105-205.

Zhang F. 1975. A new thecodont Lotosaurus, from Middle Triassic of Hunan. Vertebrata PalAsiatica 13:144-147.

Ziegler PA, Stampfli GM. 2001. Late Palaeozoic-Early Mesozoic plate boundary reorganization: collapse of the Variscan orogen and opening of Neotethys. In: Cassinis G.

(Ed.), Permian Continental Deposits of Europe and Other Areas. Regional Reports and Correlations. Annali Museo Civico Scienze Naturali, Brescia 25:17-34.

Figure captions

Fig. 1 - Geologic map of the Pianezza area. In the upper row the location of Maira Valley and Gardetta-Pianezza area. For the geologic map: 1= volcanic complex and graphitic schist (upper Carboniferous - Permian); 2= conglomerate, 3= quartz-conglomerate, and 4= quartzarenite and quartz-siltite of the quartzitic complex (upper Permian - early Lower Triassic); 5= lower carniole complex (late Lower Triassic); 6= lower calcareous complex (lower Anisian early upper Ladinian); 7= upper dolomitic complex (upper Ladinian); 8= lakes and peat bog; $9=$ faults; $10=$ location of the footprint site; in white the detritic cover and moraines.

Fig. 2 - Correlation scheme among the Briançonnais s.s., the Ligurian Briançonnais, from De Carlis \& Lualdi, 1990 redrawn and modified. PNQ: "Ponte di Nava Quartzites”, CVP: Case Val Marenca Pelites. The footprint silohuette marks the position of the track-bearing horizon. 
1132 Fig. 3 - a) Panoramic view of the track surface with the line-drawing of the chirotherian

1133 trackways. In pale yellow the above-lying bed characterized by symmetric wave ripples; b)

1134 Detailed view of the GT-1 and GT-2 trackways, highlighted with the black colour.

1135 Fig. 4 - Isochirotherium gardettensis ichnosp. nov. The GT-7 trackway, made of three

1136 consecutive manus-pes couples, is here highlighted by the red chalk and preserved in the

1137 upper track-bearing surface. Scale bar: $13 \mathrm{~cm}$.

1138

1139

1140

1141

1142

1143

1144

1145

1146

1147

1148

1149

1150

1151

1152
Fig 5. Pentadactyl tracks from the Lower and Middle Triassic, assigned to the ichnogenus Chirotherium and their comparison with the studied tracks of the Gardetta ichnosite: a) GT-13; b) GT-2-3; c) GT-2-8; d) GT-2-6; e), f) Chirotherium barthii pes manus sets from type surface of the "Thüringischer Chirotheriensandstein", Hildburghausen, Germany; g)

Chirotherium barthii pes manus set from the Holbrook Member of the Moenkopi Formation (Middle Triassic), southwest of Cameron, northern Arizona; h) Chirotherium vorbachi pes manus set from the Lower Triassic of Aura an der Saale, Germany; i), Chirotherium sickleri “Thüringischer Chirotheriensandstein”, Germany; 1) , m) Chirotherium sickleri pes manus sets from the Wupatki Member of the Moenkopi Formation (Lower Triassic), Meteor Crater, Arizona. Scale bar $10 \mathrm{~cm}$.

Fig. 6 - a) Isochirotherium gardettensis ichnosp. nov. Colour-coded and contour line image of the GT-7 trackway; b) Interpretative drawing of the GT-7 trackway.

Fig. 7 - Reconstruction of the trackmaker's fore- and hind limbs, based on the 3D model and its interpretative drawing. Dashed lines define the metatarsal of digit V held lifted off the ground during locomotion. 
1153 Fig. 8 - Pentadactyl tracks from the Lower and Middle Triassic, assigned to the ichnogenus

1154 Isochirotherium and their comparison with the studied tracks of the Gardetta ichnosite: a), b),

1155 c), pes manus sets of the GT-7 trackway; d) GT-3 isolated pes imprints of the lower track

1156 surface; e) Isochirotherium herculis pes manus set from the "Thüringischer

1157 Chirotheriensandstein" (Lower Triassic), Germany; f) Isochirotherium marshalli pes manus

1158 set from the Holbrook Member of the Moenkopi Formation (Middle Triassic), Penzance,

1159 Northern Arizona; g) Isochirotherium inferni manus pes set from the Middle Triassic (late

1160 Anisian) of Adige Valley, Bolzano, Italy; h) Isochirotherium coltoni pes manus set from the

1161 Wupatki Member of the Moenkopi Formation (Lower Triassic), Meteor Crater, Arizona; i)

1162 Isochirotherium lomasi pes manus set from the Middle Triassic (Anisian) of Cheshire, Great

1163 Britain; 1) Isochirotherium coureli pes manus set from the Middle Triassic (Anisian-Ladinian)

1164 of the Massif Central, France; m) Isochirotherium hessbergense pes manus set from the

1165 "Thüringischer Chirotheriensandstein" (Lower Triassic), Germany; n) Isochirotherium

1166 demathieui pes manus set from the Middle Triassic of Mont d'Or Lyonnais, France; o)

1167 Isochirotherium soergeli pes manus set from the "Thüringischer Chirotheriensandstein"

1168 (Lower Triassic), Germany. Scale bar $10 \mathrm{~cm}$.

1169 Fig. 9 - Fore- and hind-limb skeletons of Triassic archosauriforms and of the Isochirotherium

1170 gardettensis trackmaker. Reconstructed right pes and manus skeletons of a) the

1171 Isochirotherium gardettensis trackmaker in anterior/dorsal view; b) Postosuchus kirkpatricki,

1172 USA, Norian (redrawn from Chatterjee, 1985); c) Postosuchus alisonae, USA, Norian

1173 (redrawn from Peyer et al., 2008); d) Lotosaurus adentus, China, Ladinian (redrawn from

1174 http://www.reptileevolution.com/lotosaurus.htm.jpg); e) Proterosuchus fergusi, South Africa,

1175 Induan-?early Olenekian (redrawn from Broom, 1903); f) Erythrosuchus africanus, South 
1176

1177

1178

1179

1180

1181

1182

1183

1184

1185

1186

1187

1188

1189

1190

1191

1192

1193

1194

1195

1196

Africa, early Anisian (redrawn from Broom, 1905); g) Shansisuchus shansisuchus, China, late Anisian (redrawn from Young, 1964 and http://www.reptileevolution.com/shansisuchus.htm); h) Euparkeria capensis, South Africa, Anisian (redrawn from Broom, 1913); i)

Chanaresuchus bonapartei Romer, 1971, Argentina, Ladinian. Scale bars: a), b), c), d), f) g) = $10 \mathrm{~cm}$; e), h) and i) $=1 \mathrm{~cm}$.

Fig. 10 - Life appearance of the non-archosaurian archosauriform (erythrosuchid?) the most suitable producer of Isochirotherium gardettensis. Simplified reconstruction of fore and hind autopodials in bottom (a) view. Complete life reconstruction in bottom (b), back (c), frontal (d) and lateral view (e) of the trackmaker. The gait and fore- and hind limbs were reconstructed according to the pattern and morphologies of GT-7 trackway (artwork by Fabio Manucci). See the supplementary video to get a more complete view of the reconstruction.

Fig. 11 - Paleogeographic distribution of Early Triassic archosauriform footprints (yellow stars) and body fossil localities across Pangea. Black square = indeterminate archosauromorphs, red circles $=$ non-archosauriform archosauromorphs, blue stars $=$ archosauriforms. The palaeolatitude estimate for the southern Briançonnais domain is $11.8 \mathrm{~N}$ in the Olenekian (250 $\mathrm{Ma}$ ), confirming that archosauriforms were distributed also at low latitudes, in the tropical humid climatic belt. ImagePaleomap for 250 Ma downloaded from Fossilworks using data from the Paleobiology Database (Alroy, 2003). Redrawn and modified from Bernardi et al. (2015) and Benton (2018).

Table 1 - Specimen number, taxonomic affinities and repository for all the ichnological material from Gardetta considered in the present contribution. 


\section{Figure 1}

Geologic map of the Pianezza area

Geologic map of the Pianezza area. In the upper row the location of Maira Valley and Gardetta-Pianezza area. For the geologic map: 1= volcanic complex and graphitic schist (upper Carboniferous - Permian); 2 = conglomerate, $3=$ quartz-conglomerate, and $4=$ quartzarenite and quartz-siltite of the quartzitic complex (upper Permian - early Lower Triassic); 5= lower carniole complex (late Lower Triassic); $6=$ lower calcareous complex (lower Anisian early upper Ladinian); 7= upper dolomitic complex (upper Ladinian); 8= lakes and peat bog; $9=$ faults; $10=$ location of the footprint site; in white the detritic cover and moraines. 


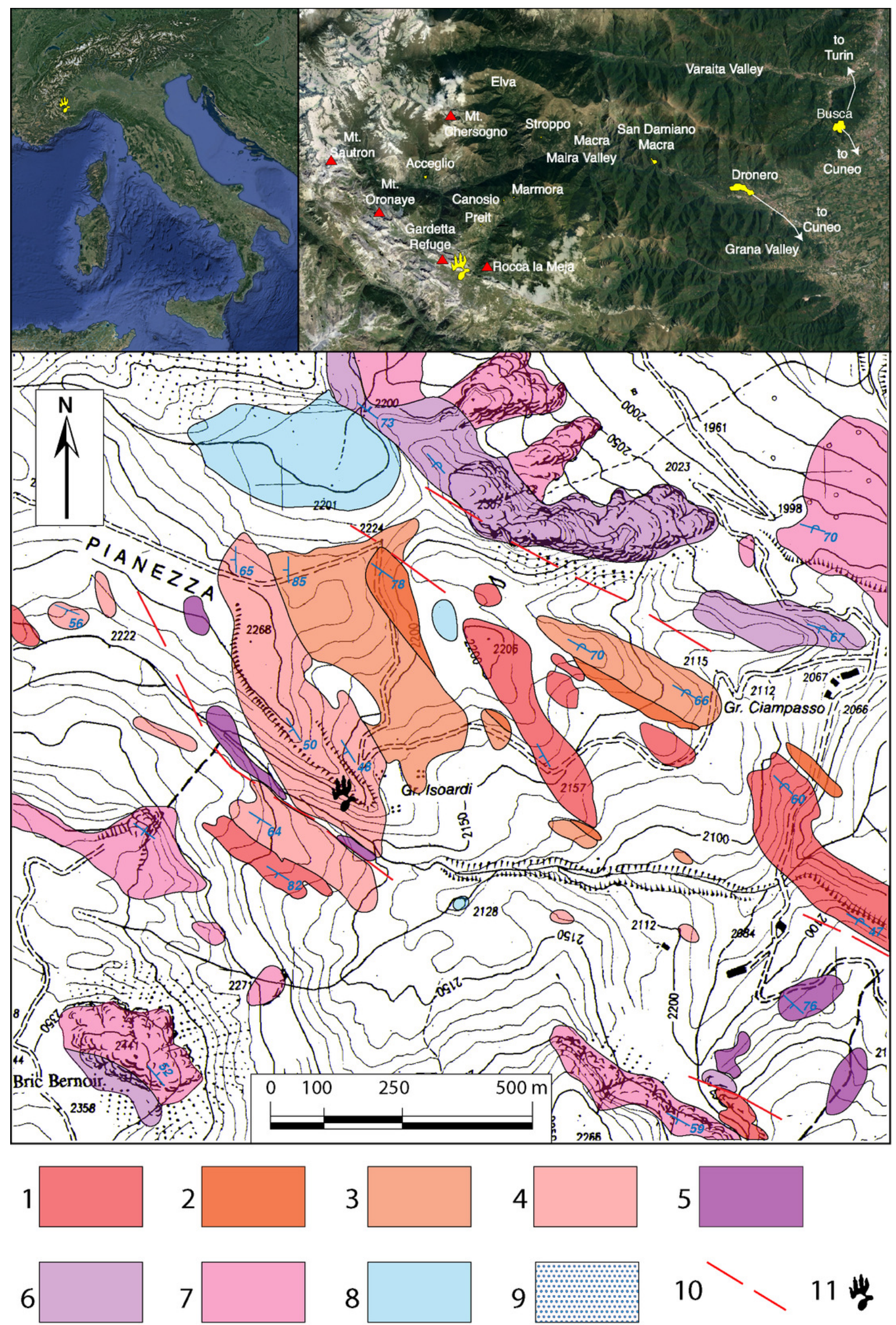


Figure 2

Correlation scheme among the Briançonnais s.s.

Correlation scheme among the Briançonnais s.s., the Ligurian Briançonnais, from De Carlis \& Lualdi, 1990 redrawn and modified. PNQ: "Ponte di Nava Quartzites", CVP: Case Val Marenca Pelites. The footprint silohuette marks the position of the track-bearing horizon. 


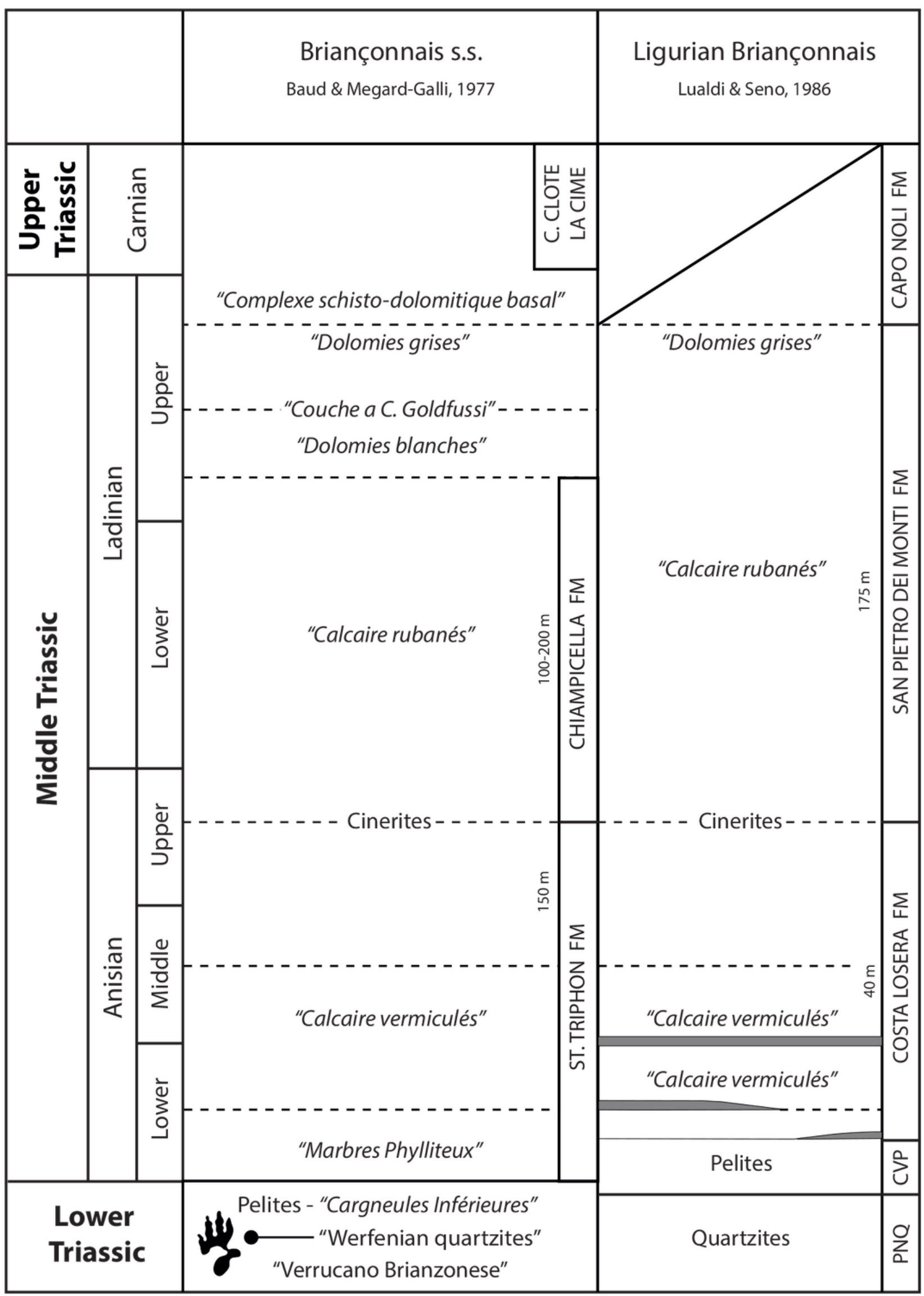


Figure 3

Panoramic view of the track surface

a) Panoramic view of the track surface with the line-drawing of the chirotherian trackways. In pale yellow the above-lying bed characterized by symmetric wave ripples; b) Detailed view of the GT-1 and GT-2 trackways, highlighted with the black colour. 

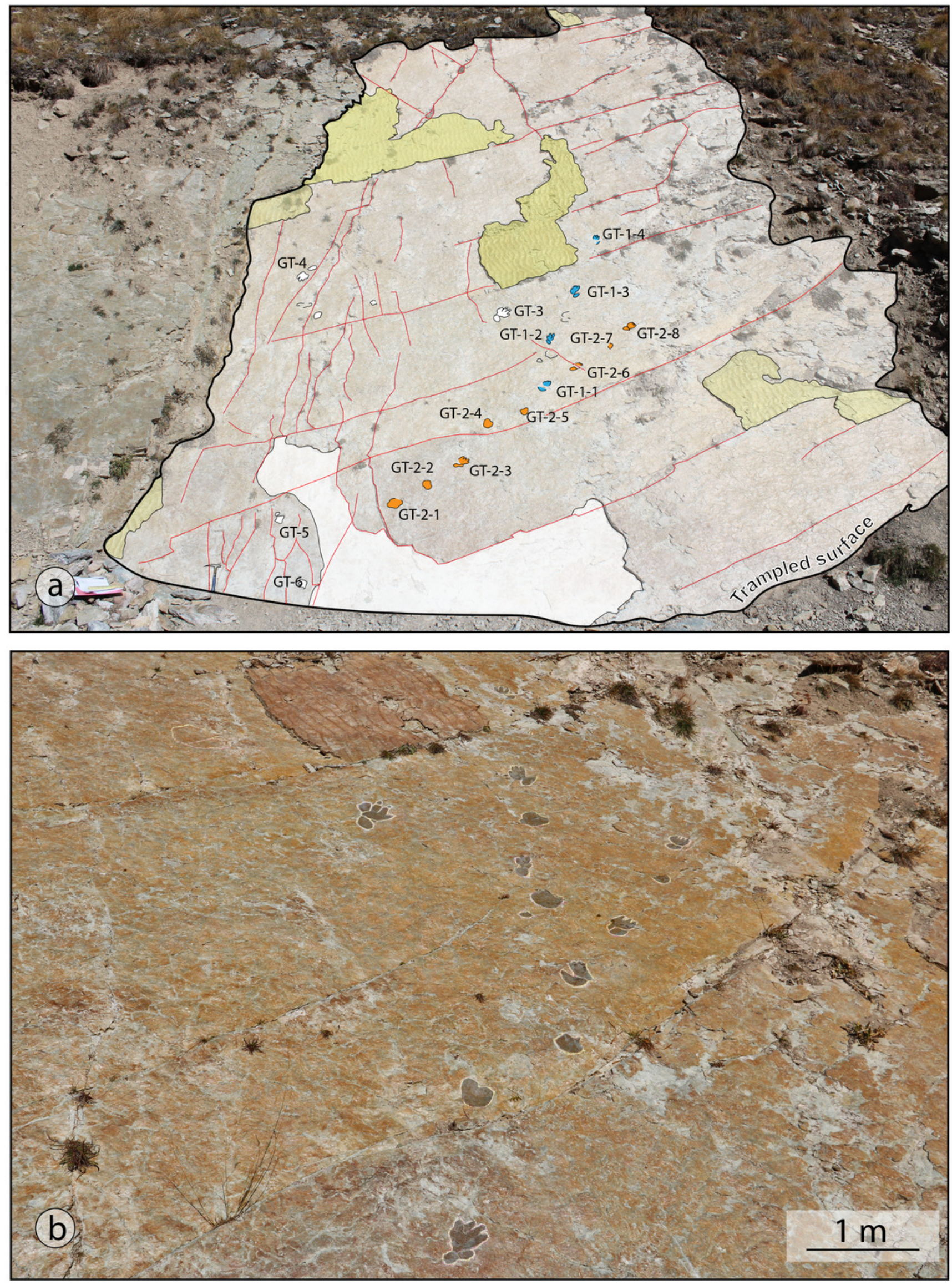


\section{Figure 4}

The GT-7 trackway of Isochirotherium gardettensis ichnosp. nov.

Isochirotherium gardettensis ichnosp. nov. The GT-7 trackway, made of three consecutive manus-pes couples, is here highlighted by the red chalk and preserved in the upper trackbearing surface. Scale bar: $13 \mathrm{~cm}$.

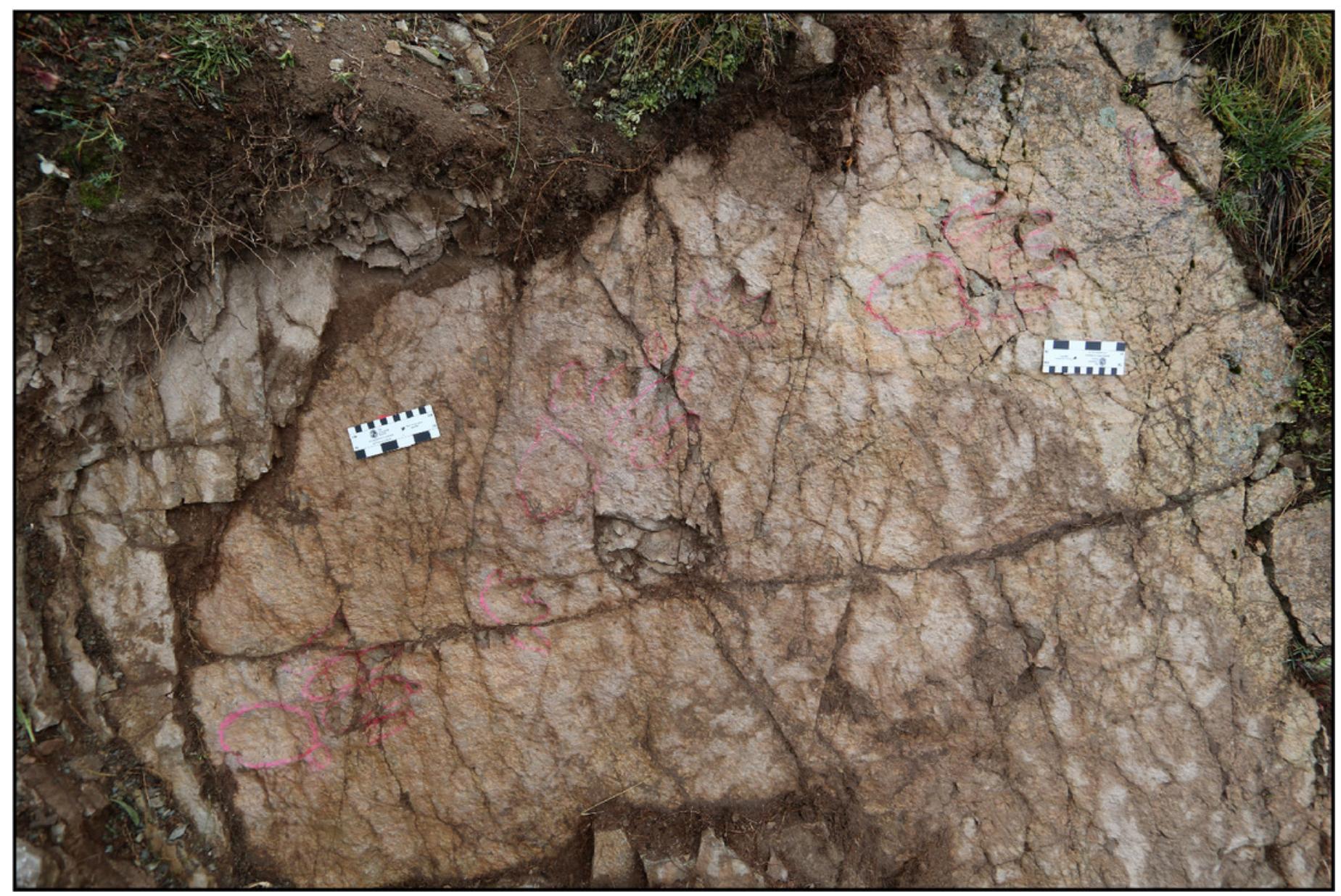




\section{Table $\mathbf{1}$ (on next page)}

ichnological material from Gardetta

Specimen number, taxonomic affinities and repository for all the ichnological material from Gardetta considered in the present contribution 


\begin{tabular}{|c|c|c|}
\hline Number of specimen & Ichnotaxonomy & Repository \\
\hline GT-1-1 & Chirotherium isp. & Left in situ in the outcrop \\
\hline GT-1-2 & Chirotherium isp. & Left in situ in the outcrop \\
\hline GT-1-3 & Chirotherium isp. & Left in situ in the outcrop \\
\hline GT-1-4 & Chirotherium isp. & Left in situ in the outcrop \\
\hline GT-2-1 & Chirotherium isp. & Left in situ in the outcrop \\
\hline GT-2-2 & Chirotherium isp. & Left in situ in the outcrop \\
\hline GT-2-3 & Chirotherium isp. & Left in situ in the outcrop \\
\hline GT-2-4 & Chirotherium isp. & Left in situ in the outcrop \\
\hline GT-2-5 & Chirotherium isp. & Left in situ in the outcrop \\
\hline GT-2-6 & Chirotherium isp. & Left in situ in the outcrop \\
\hline GT-2-7 & Chirotherium isp. & Left in situ in the outcrop \\
\hline GT-2-8 & Chirotherium isp. & Left in situ in the outcrop \\
\hline GT-3 & Isochirotherium isp. & Left in situ in the outcrop \\
\hline GT-4 & unnamed footprint & Left in situ in the outcrop \\
\hline GT-5 & unnamed footprint & Left in situ in the outcrop \\
\hline GT-6 & unnamed footprint & Left in situ in the outcrop \\
\hline GT-7-1 & Isochirotherium gardettensis & Left in situ in the outcrop \\
\hline GT-7-2 & Isochirotherium gardettensis & Left in situ in the outcrop \\
\hline $\begin{array}{l}\text { GT-7-3 (Digital cast MGPT- } \\
\text { PU1357853) }\end{array}$ & Isochirotherium gardettensis & $\begin{array}{l}\text { Left in situ in the outcrop. } \\
\text { 3D printing stored at the Museo di } \\
\text { Geologia e Paleontologia } \\
\text { dell'Università di Torino and } \\
\text { digitally stored in MorphoSource }\end{array}$ \\
\hline GD-E1 & unnamed footprint & $\begin{array}{l}\text { Loose slab stored at the Museo di } \\
\text { Geologia e Paleontologia } \\
\text { dell'Università di Torino }\end{array}$ \\
\hline GD-E2 & unnamed footprint & $\begin{array}{l}\text { Loose slab stored at the Museo di } \\
\text { Geologia e Paleontologia } \\
\text { dell'Università di Torino }\end{array}$ \\
\hline GD-E12 & unnamed footprint & $\begin{array}{l}\text { Loose slab stored at the Museo di } \\
\text { Geologia e Paleontologia } \\
\text { dell'Università di Torino }\end{array}$ \\
\hline
\end{tabular}




\section{Figure 5}

Pentadactyl tracks from the Lower and Middle Triassic, assigned to the ichnogenus Chirotherium and their comparison with the studied tracks of the Gardetta ichnosite

Pentadactyl tracks from the Lower and Middle Triassic, assigned to the ichnogenus Chirotherium and their comparison with the studied tracks of the Gardetta ichnosite: a) GT-1-3; b) GT-2-3; c) GT-2-8; d) GT-2-6; e), f) Chirotherium barthii pes manus sets from type surface of the "Thüringischer Chirotheriensandstein", Hildburghausen, Germany; g) Chirotherium barthii pes manus set from the Holbrook Member of the Moenkopi Formation (Middle Triassic), southwest of Cameron, northern Arizona; h) Chirotherium vorbachi pes manus set from the Lower Triassic of Aura an der Saale, Germany; i), Chirotherium sickleri "Thüringischer Chirotheriensandstein", Germany; I) , m) Chirotherium sickleri pes manus sets from the Wupatki Member of the Moenkopi Formation (Lower Triassic), Meteor Crater, Arizona. Scale bar $10 \mathrm{~cm}$. 


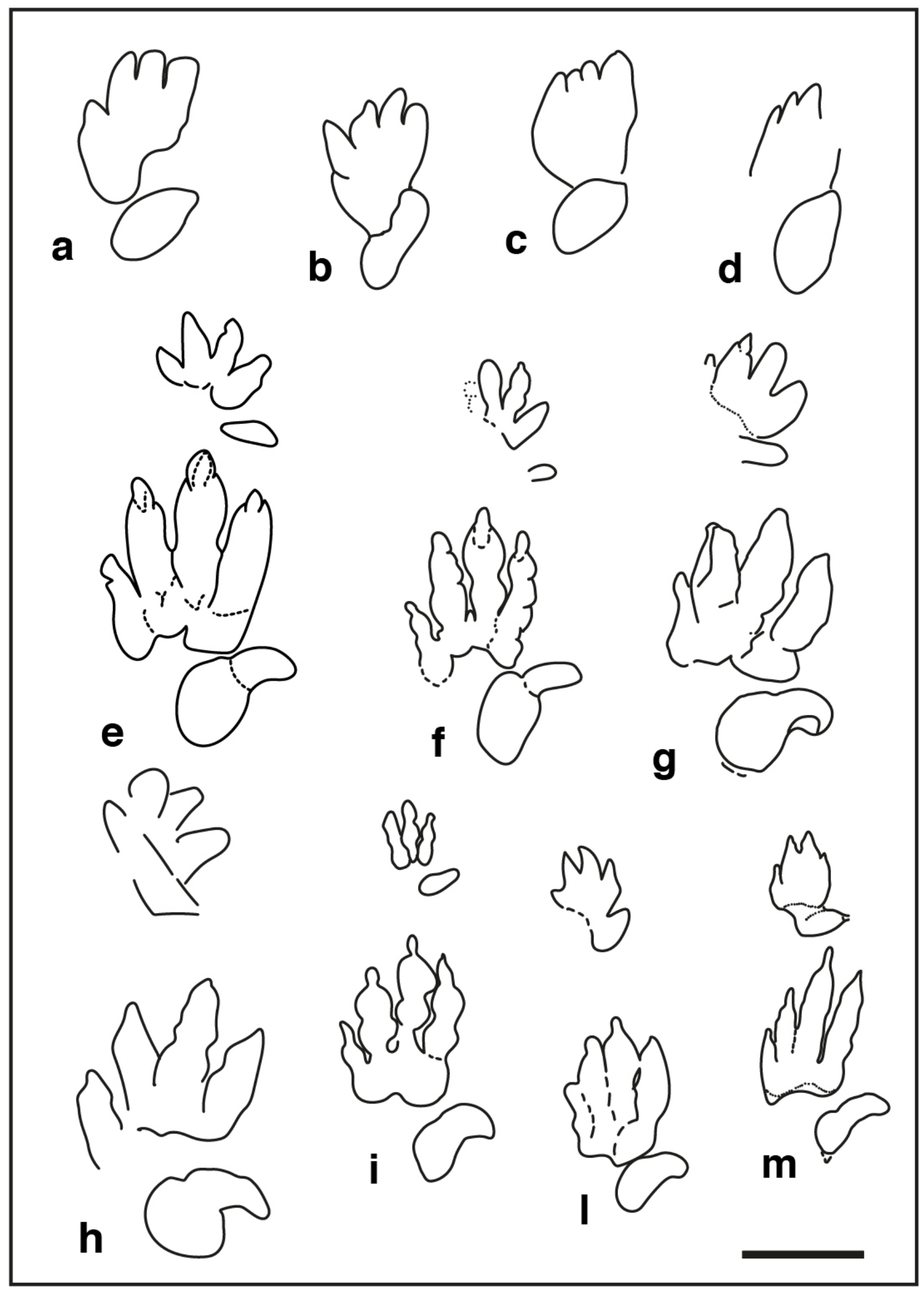

Peer] reviewing PDF | (2020:08:51782:4:0:NEW 15 Nov 2020) 


\section{Figure 6}

Colour-coded, contour line and interpretative drawing of the GT-7 trackway

a) Isochirotherium gardettensis ichnosp. nov. Colour-coded and contour line image of the GT-7 trackway; b) Interpretative drawing of the GT-7 trackway.

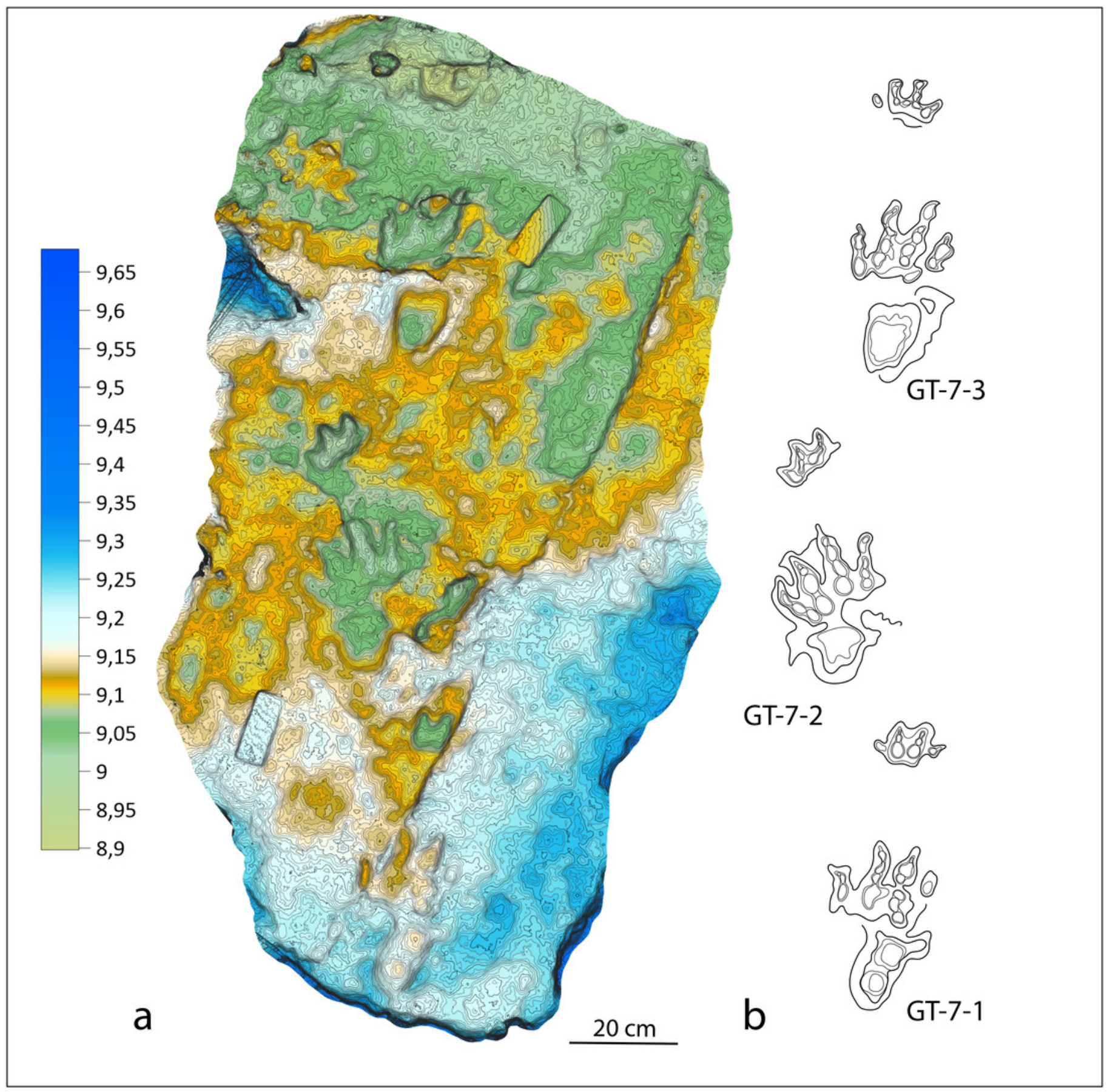




\section{Figure 7}

Reconstruction of the trackmaker's fore- and hind limbs

Reconstruction of the trackmaker's fore- and hind limbs, based on the 3D model and its interpretative drawing. Dashed lines define the metatarsal of digit $\mathrm{V}$ held lifted off the ground during locomotion. 


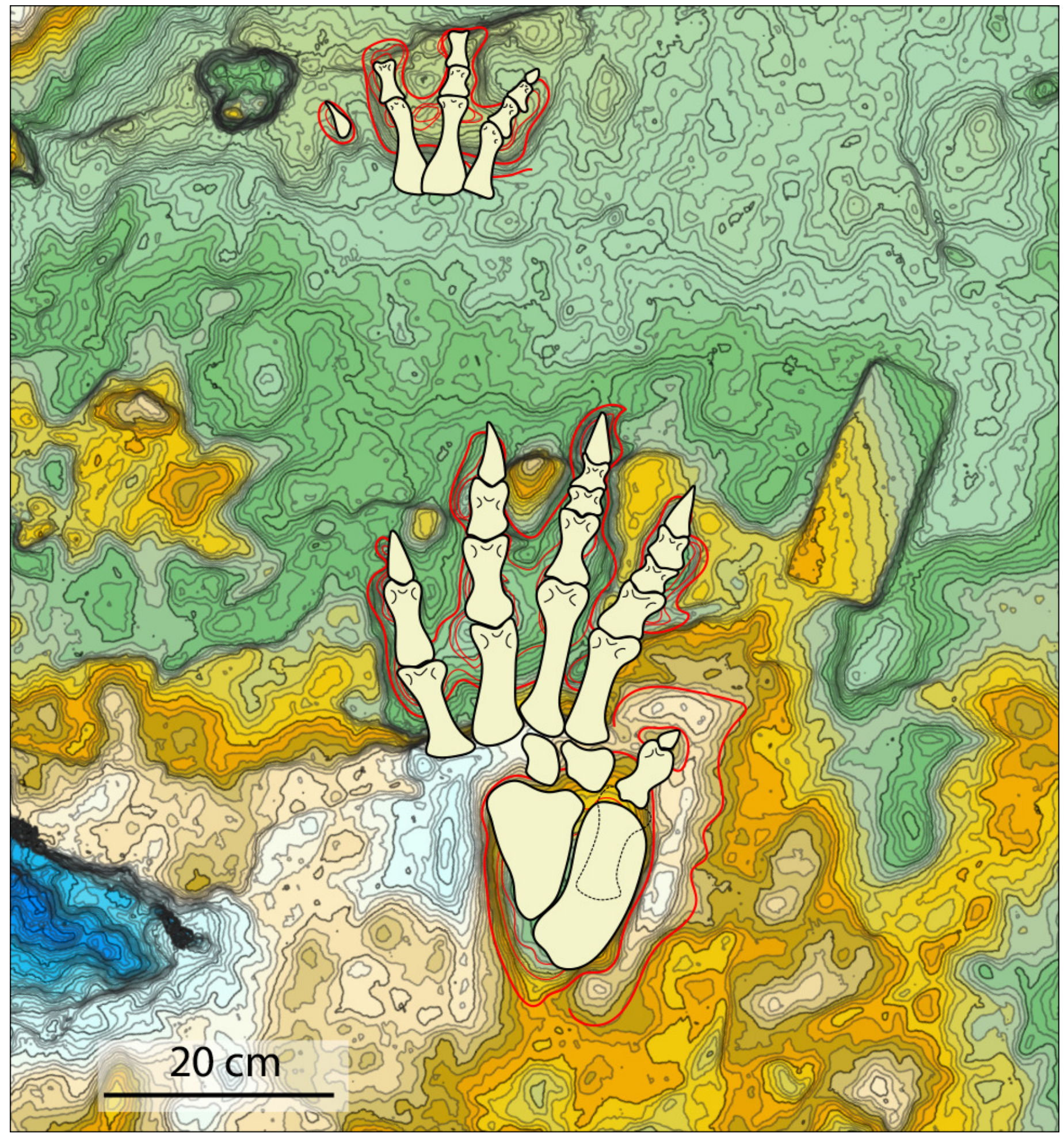




\section{Figure 8}

Pentadactyl tracks from the Lower and Middle Triassic, assigned to the ichnogenus Isochirotherium and their comparison with the studied tracks of the Gardetta ichnosite

Pentadactyl tracks from the Lower and Middle Triassic, assigned to the ichnogenus Isochirotherium and their comparison with the studied tracks of the Gardetta ichnosite: a), b), c), pes manus sets of the GT-7 trackway; d) GT-3 isolated pes imprints of the lower track surface; e) Isochirotherium herculis pes manus set from the "Thüringischer Chirotheriensandstein" (Lower Triassic), Germany; f) Isochirotherium marshalli pes manus set from the Holbrook Member of the Moenkopi Formation (Middle Triassic), Penzance, Northern Arizona; g) Isochirotherium inferni manus pes set from the Middle Triassic (late Anisian) of Adige Valley, Bolzano, Italy; h) Isochirotherium coltoni pes manus set from the Wupatki Member of the Moenkopi Formation (Lower Triassic), Meteor Crater, Arizona; i) Isochirotherium lomasi pes manus set from the Middle Triassic (Anisian) of Cheshire, Great Britain; I) Isochirotherium coureli pes manus set from the Middle Triassic (Anisian-Ladinian) of the Massif Central, France; m) Isochirotherium hessbergense pes manus set from the "Thüringischer Chirotheriensandstein" (Lower Triassic), Germany; n) Isochirotherium demathieui pes manus set from the Middle Triassic of Mont d'Or Lyonnais, France; 0) Isochirotherium soergeli pes manus set from the "Thüringischer Chirotheriensandstein" (Lower Triassic), Germany. Scale bar $10 \mathrm{~cm}$. 


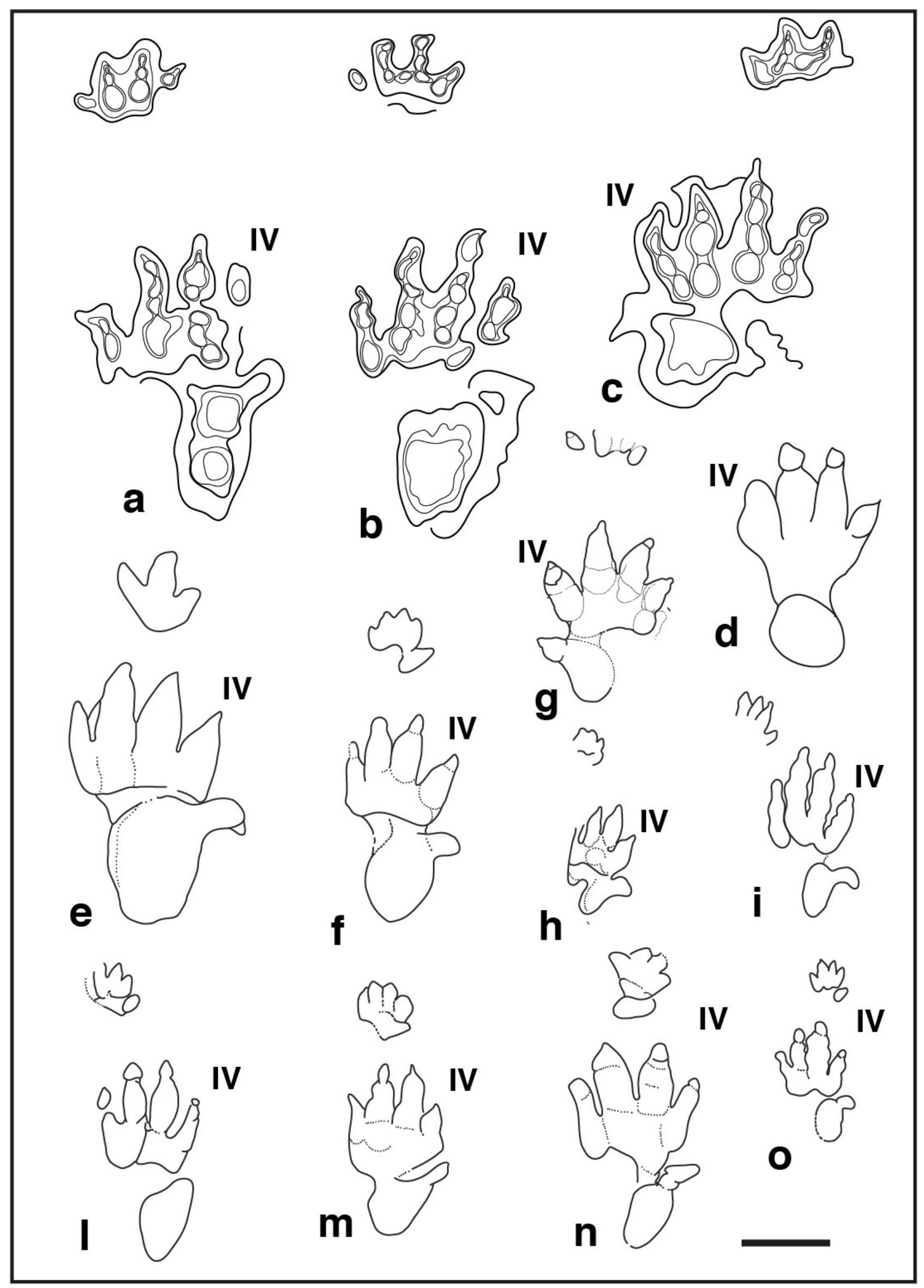




\section{Figure 9}

Fore- and hind-limb skeletons of Triassic archosauriforms and of the Isochirotherium gardettensis trackmaker

Fore- and hind-limb skeletons of Triassic archosauriforms and of the Isochirotherium gardettensis trackmaker. Reconstructed right pes and manus skeletons of a) the Isochirotherium gardettensis trackmaker in anterior/dorsal view; b) Postosuchus kirkpatricki, USA, Norian (redrawn from Chatterjee, 1985); c) Postosuchus alisonae, USA, Norian (redrawn from Peyer et al., 2008); d) Lotosaurus adentus, China, Ladinian (redrawn from Zhang, 1975); e) Proterosuchus fergusi, South Africa, Induan-?early Olenekian (redrawn from Broom, 1903); f) Erythrosuchus africanus, South Africa, early Anisian (redrawn from Broom, 1905); g) Shansisuchus shansisuchus, China, late Anisian (redrawn from Young, 1964); h) Euparkeria capensis, South Africa, Anisian (redrawn from Broom, 1913); i) Chanaresuchus bonapartei Romer, 1971, Argentina, Ladinian. Scale bars: a), b), c), d), f) g) $=10 \mathrm{~cm}$; e), h) and i) $=1$ $\mathrm{cm}$. 


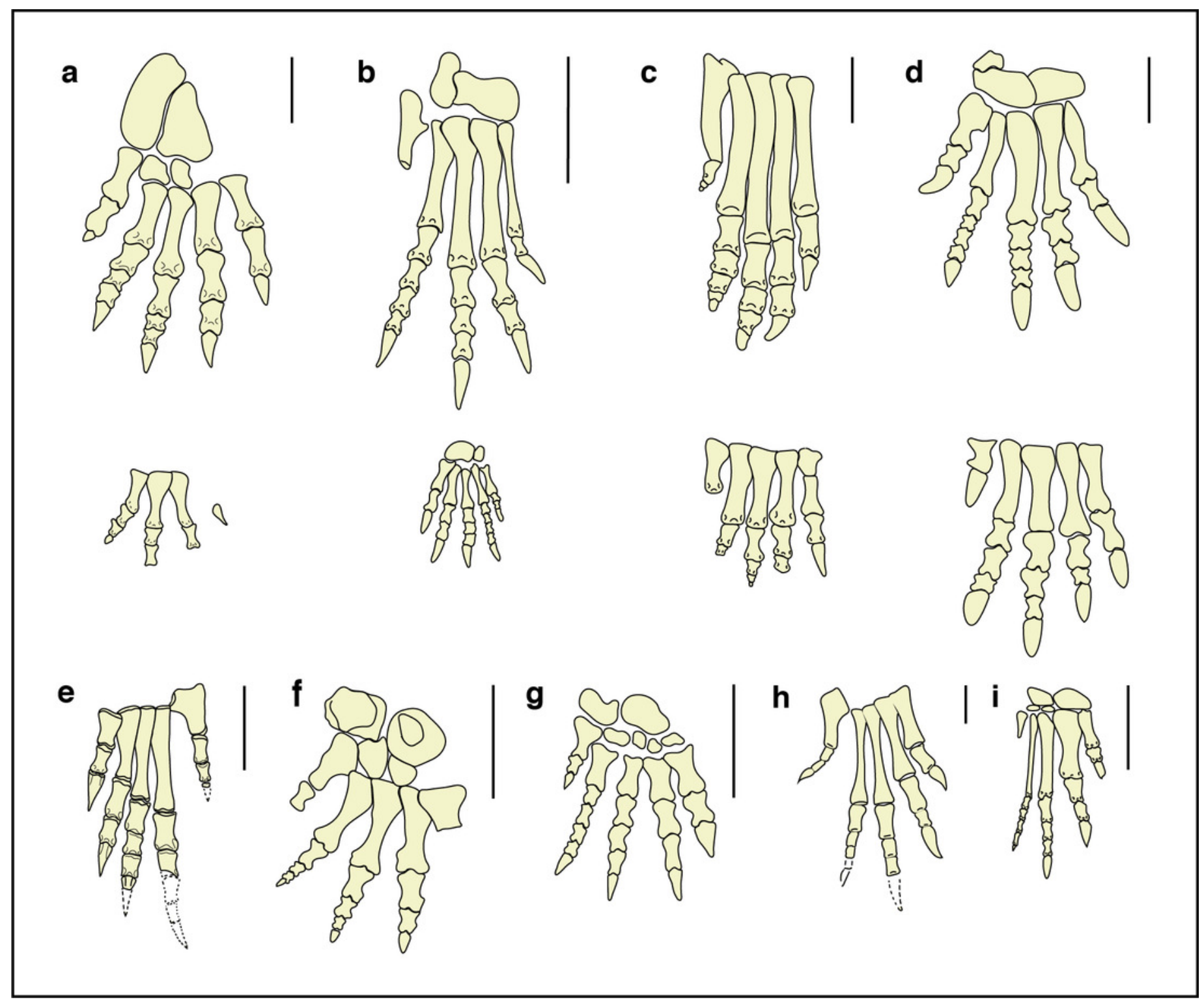




\section{Figure 10}

Life appearance of the non-archosaurian archosauriform (erythrosuchid?) the most suitable producer of Isochirotherium gardettensis

Life appearance of the non-archosaurian archosauriform (erythrosuchid?) the most suitable producer of Isochirotherium gardettensis. Simplified reconstruction of fore and hind autopodials in bottom (a) view. Complete life reconstruction in bottom (b), back (c), frontal (d) and lateral view (e) of the trackmaker. The gait and fore- and hind limbs were reconstructed according to the pattern and morphologies of GT-7 trackway (artwork by Fabio Manucci). See the supplementary video to get a more complete view of the reconstruction.
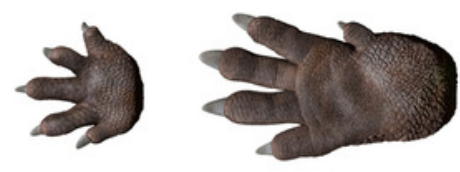

a

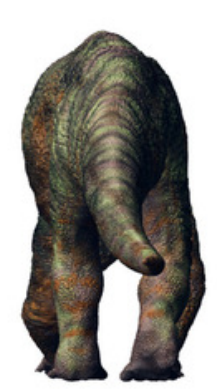

C
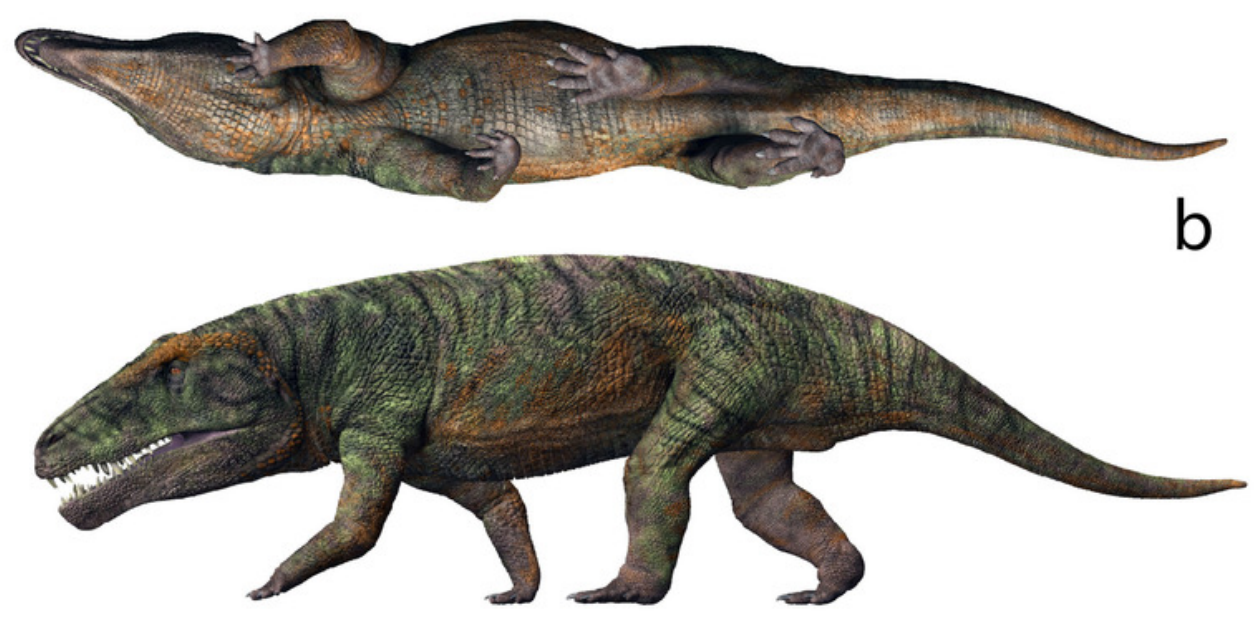

e 


\section{Figure 11}

Paleogeographic distribution of Early Triassic archosauriform footprints (yellow stars) and body fossil localities across Pangea

Paleogeographic distribution of Early Triassic archosauriform footprints (yellow stars) and body fossil localities across Pangea. Black square $=$ indeterminate archosauromorphs, red circles $=$ non-archosauriform archosauromorphs, blue stars $=$ archosauriforms. The palaeolatitude estimate for the southern Briançonnais domain is $11.8 \mathrm{~N}$ in the Olenekian (250 Ma), confirming that archosauriforms were distributed also at low latitudes, in the tropical humid climatic belt. ImagePaleomap for $250 \mathrm{Ma}$ downloaded from Fossilworks using data from the Paleobiology Database (Alroy, 2003). Redrawn and modified from Bernardi et al. (2015) and Benton (2018).

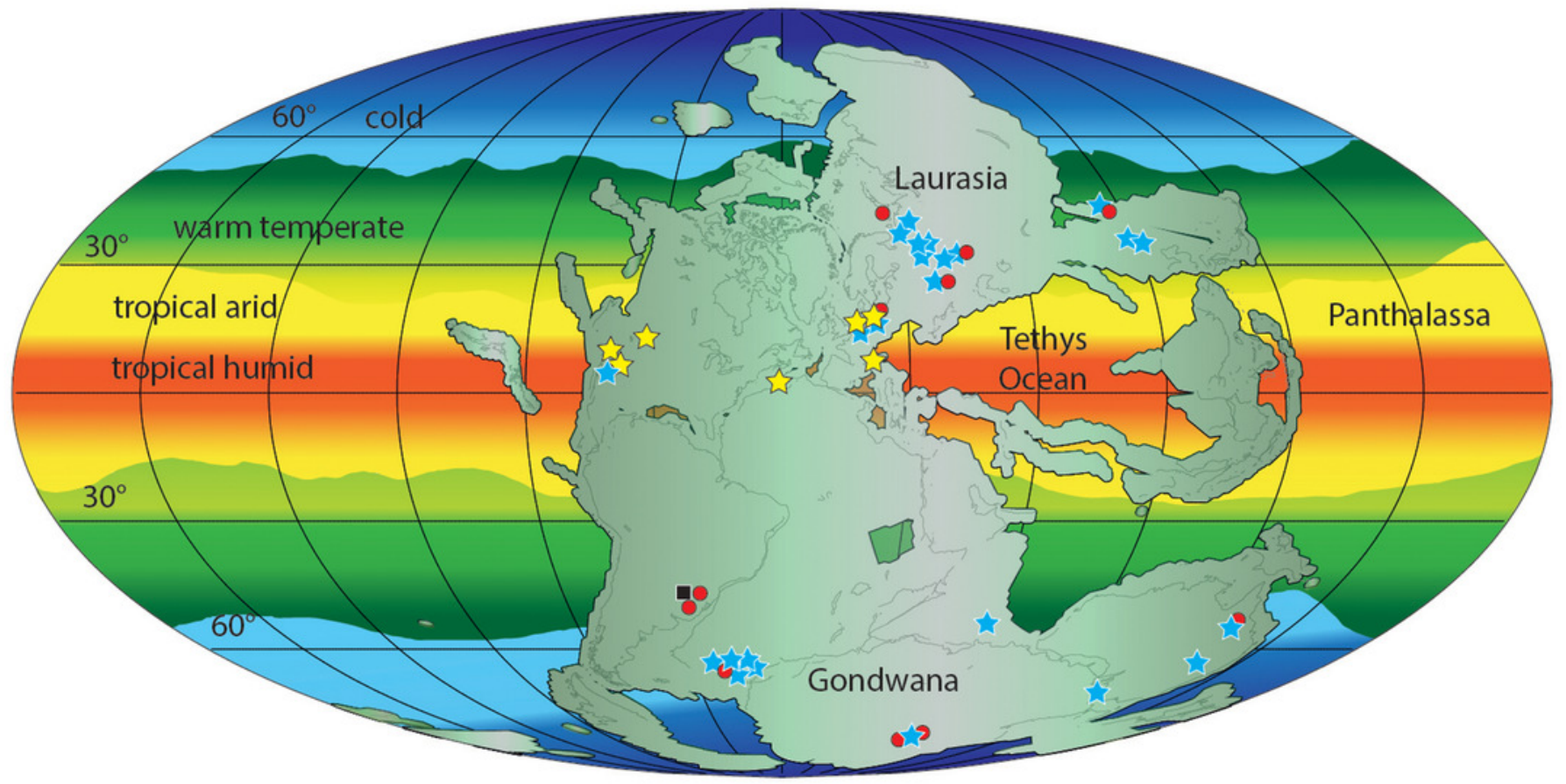

